TRANSGÊNICOS: OPINIÃO DE PROFESSORES E ALUNOS DE NÍVEL MÉDIO DA ÁREA DE NUTRIÇÃO

ANA CLÁUDIA CAYRES DE MENDONÇA

Dissertação apresentada à Escola Superior de Agricultura”Luiz de Queiroz”, Universidade de São Paulo, para obtenção do título

Mestre em Ciências. Área de Concentração:

Ciência e Tecnologia de Alimentos.

PIRACICABA

Estado de São Paulo - Brasil

Julho - 2005 
TRANSGÊNICOS: OPINIÃO DE PROFESSORES E ALUNOS DE NÍVEL MÉDIO DA ÁREA DE NUTRIÇÃO

ANA CLÁUDIA CAYRES DE MENDONÇA

Orientadora: Prof ${ }^{\mathrm{a}}$. $\mathrm{D}^{\mathrm{ra}}$. MARINA VIEIRA DA SILVA

Dissertação apresentada à Escola Superior de Agricultura”Luiz de Queiroz”, Universidade de São Paulo, para obtenção do título

Mestre em Ciências. Área de Concentração:

Ciência e Tecnologia de Alimentos.

PIRACICABA

Estado de São Paulo - Brasil

Julho - 2005 
Dados Internacionais de Catalogação na Publicação (CIP) DIVISÃO DE BIBLIOTECA E DOCUMENTAÇÃO - ESALQ/USP

Mendonça, Ana Cláudia Cayres de

Transgênicos: opinião de professores e alunos de nível médio da área / Ana Cláudia Cayres de Mendonça. - - Piracicaba, 2005.

80 p. : il.

Dissertação (Mestrado) - - Escola Superior de Agricultura Luiz de Queiroz, 2005.

Bibliografia.

1. Alimentos transgênicos 2. Consumidor 3. Segurança alimentar 4. Valor nutritivo I. Título

CDD 664

"Permitida a cópia total ou parcial deste documento, desde que citada a fonte - O autor" 
Dedico este trabalho às pessoas mais importantes de minha vida:

Aos meus pais, Louis e Glória, pelo carinho, pela paciência, pelas palavras de encorajamento que me fortaleceram nos momentos mais conturbados desta caminhada e pelo apoio financeiro, sem os quais a realização deste trabalho não seria possível.

Aos meus irmãos Thaís e Victor, os quais, mesmo à distância, sempre me apoiaram e me incentivaram durante todas os etapas de minha vida.

Ao Nilo, pelo carinho, pelo incentivo e pela compreensão 


\section{AGRADECIMENTOS}

À Prof ${ }^{\mathrm{a}} \mathrm{D}^{\text {ra }}$. Marina Vieira da Silva pela orientação, pela motivação constante e pelo apoio concedidos durante esta fase tão importante de minha vida.

À Prof ${ }^{\mathrm{a}} \mathrm{D}^{\mathrm{ra}}$. Maria Angélica Pennatti Pipitone, pelas contribuições ao trabalho.

Às bibliotecárias da ESALQ, especialmente a Beatriz Helena Giongo (Bia), pelas orientações fornecidas durante todo o curso e durante a revisão da dissertação.

À Prof ${ }^{\mathrm{a}} \mathrm{D}^{\mathrm{ra}}$. Solange Guidolin Canniatti Brazaca, pelas contribuições ao trabalho.

A todos os professores de pós-graduação da área de Ciência e Tecnologia de Alimentos da Esalq, pelos valiosos ensinamentos.

A todos os funcionários do Departamento de Agroindústria, Alimentos e Nutrição, pela atenção.

À Prof ${ }^{\mathrm{a}} \mathrm{D}^{\text {ra }}$. Maria da Conceição Pereira da Fonseca, pelas contribuições ao trabalho.

Aos meus amigos do curso, especialmente à Flávia, Patrícia, Márcia, Thaís, Ana Paula, pelo apoio, carinho, companheirismo e pelos momentos de descontração.

À Mariana Branco de Miranda, por todos os momentos compartilhados e pela dedicação. 
Aos meus colegas de trabalho Aline, Alberto, Roberta, Eduardo, Cristine, Flávio,

Celeste, Cíntia, Débora, Rafaela, pelo apoio. Ao Vitor Biolchi, pela compreensão e pelo incentivo.

Aos Coordenadores do Centro Estadual de Educação Tecnológica Paula Souza, Maria Lúcia Mendes Carvalho e Almério Melquíades de Araújo, pelo interesse na pesquisa e disposição oferecida, que possibilitaram o acesso aos dados.

A todos os Diretores, Coordenadores, Professores e Alunos das Escolas do Centro Paula Souza visitadas, pela receptividade e auxílio na coleta de dados.

A todos que eu não tenha mencionado, mas que fizeram parte deste trabalho, agradeço. 


\section{SUMÁRIO}

Página

LISTA DE TABELAS............................................................................ viii

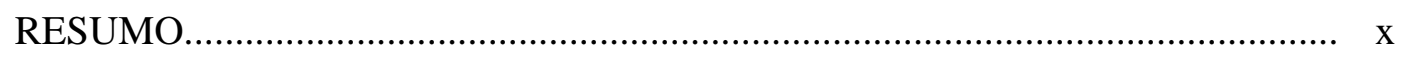

SUMMARY ......................................................................................... xii

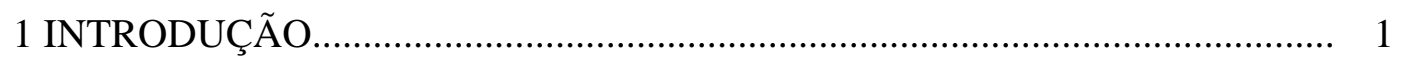

2 REVISÃO DE LITERATURA................................................................ 4

2.1 Biotecnologia: Breve Histórico....................................................................... 5

2.2 Transgênicos.......................................................................................... 8

2.3 Segurança Alimentar e Nutricional: o caso dos transgênicos............................ 9

2.4 Produção de Transgênicos............................................................................... 13

2.5 Legislação de Transgênicos........................................................................... 15

2.5.1 A polêmica da soja Roundup Ready ${ }^{\circledR}$........................................................ 16

2.5.2 Órgão Regulador........................................................................... 17

2.5.3 Normas de Rotulagem....................................................................... 18

2.6 Transgênicos: Europa e Estados Unidos......................................................... 20

2.7 Transgênicos: Posição de Organismos Internacionais e Nacionais.................. 23

2.8 O Comportamento do consumidor ............................................................ 24

3 MATERIAL E MÉTODOS.......................................................................... 27

3.1 População de estudo................................................................................... 27

3.2 Análise de dados................................................................................. $\quad 30$ 
4 RESULTADOS E DISCUSS ÃO .................................................................. 31

4.1 Caracterização dos participantes da pesquisa: aspectos socioeconômicos, estilo de vida e atitudes relativas à aquisição e consumo de alimentos............. 31

4.2 Conhecimento e opinião dos entrevistados no tocante a transgenia................. 35

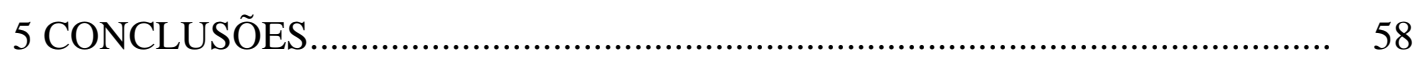

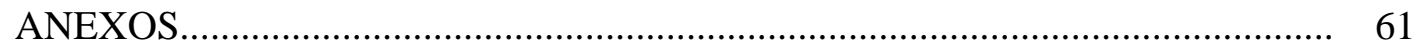

REFERÊNCIAS BIBLIOGRÁFICAS........................................................ 78 


\section{LISTA DE TABELAS}

Página

1 Tópicos que distinguem biotecnologia clássica e biotecnologia moderna.......... 6

2 Principais países produtores de transgênicos, entre os anos 2002 e 2004 ....... 15

3 Distribuição dos professores e alunos integrantes da pesquisa de acordo com a faixa de renda pessoal e a renda familiar (em salários mínimos). São Paulo, 2004...

4 Atributos dos alimentos, considerados durante o processo de compra, citados por professores e alunos. São Paulo, 2004.

5 Distribuição percentual das citações dos professores e alunos de acordo com o conceito relativo aos produtos/alimentos transgênicos.São Paulo, 2004.

6 Tipos de notícias veiculadas pela mídia sobre transgênicos, citadas por professores e alunos. São Paulo, 2004.

7 Citações dos professores e alunos no tocante à crença de que o Brasil poderá elaborar legislação especifica à biotecnologia. São Paulo, 2004

8 Citações dos professores e alunos relativas à crença que o uso de sementes transgênicas poderá alterar os preços dos alimentos. São Paulo, 2004.

9 Citações dos professores e alunos relativas a crença que os alimentos transgênicos poderão contribuir para diminuir o contingente de indivíduos expostos à fome ,em distintos paises.São Paulo, 2004. 
11 Citações dos professores relativas à penalidade que acreditam deveriam ser impostas para os agentes que não cumprirem a legislação relativa à rotulagem. São Paulo, 2004

12 Citações dos professores relativas à crença que a economia brasileira poderá se beneficiar em decorrência da produção e comercialização de transgênicos. São Paulo, 2004.

13 Disposição dos professores e alunos de pagar valores adicionais por produtos comprovadamente não-transgênicos. São Paulo, 2004.

14 Citações dos professores e alunos relativas aos possíveis impactos ao meio ambiente, decorrentes do uso de sementes transgênicas. São Paulo, 2004........

15 Posição de professores e alunos com relação ao uso de alimentos transgênicos, como soja e milho, na ração para animais. São Paulo, 2004........

16 Citações dos professores e alunos relativas à crença sobre a superioridade dos alimentos orgânicos comparativamente aos transgênicos. São Paulo 2004.

17 Distribuição das citações dos professores e alunos, de acordo com as fontes consultadas para a conceituação de que alimentos orgânicos sejam superiores aos transgênicos. São Paulo,2004.

18 Distribuição dos professores e alunos, de acordo com o costume e a freqüência de consumo de alimentos orgânicos. São Paulo, 2004. 


\title{
TRANSGÊNICOS: OPINIÃO DE PROFESSORES E ALUNOS DE NÍVEL MÉDIO DA ÁREA DE NUTRIÇÃO
}

\author{
Autora: ANA CLÁUDIA CAYRES DE MENDONÇA \\ Orientadora: Prof ${ }^{\mathrm{a}}$. $\mathrm{D}^{\text {ra }}$. MARINA VIEIRA DA SILVA
}

\section{RESUMO}

O emprego de organismos transgênicos divide opiniões e, portanto, é causa de grande polêmica. Apesar da existência de vasto rol de publicações que registram os benefícios decorrentes do desenvolvimento da transgenia, são verificados sinais de inquietação por parte dos consumidores quanto ao seu emprego na produção de alimentos. Tal comportamento freqüentemente decorre da falta de informações claras e emitidas por agências que desfrutam da confiança dos consumidores. A presente pesquisa buscou conhecer o nível de informação de professores e alunos de cursos técnicos em nutrição, mantidos por escolas públicas e situadas em diferentes regiões e municípios do Estado de São Paulo. Foi elaborado e adotado um questionário para os professores, contendo 33 questões descritivas e objetivas, e um para os alunos, com 26 questões, também com o envolvimento de questões das referidas modalidades. Ambos instrumentos referiam-se à opinião dos entrevistados em relação ao uso da transgenia. Cabe ressaltar que, nestes questionários, também foram incluídas questões referentes à situação socioeconômica e aos hábitos alimentares destes professores. Para a análise dos dados foram utilizados os softwares Excel e o SAS. 
Do total de professores e alunos escolhidos para integrarem a amostra, 38\% e 69,3\%, respectivamente, concordaram em participar da pesquisa, totalizando-se 42 professores e 277 alunos entrevistados, oriundos de nove escolas. A maioria dos professores registrou respostas, consideradas pertinentes, às questões relacionadas ao tema "transgênicos", embora se esperasse que as citações envolvessem o uso de termos mais precisos, visto os integrantes da amostra serem graduados, e, em grande parte, pós-graduados, em diversas áreas afins das ciências biológicas. A maioria dos alunos também respondeu às referidas questões, embora, também, de maneira superficial. Substancial parcela dos professores (62\%) não soube afirmar se alimentos/produtos transgênicos são benéficos ou maléficos ao homem, situação esta já esperada, em virtude da escassez de informações sobre as conseqüências que o consumo destes alimentos podem trazer ao homem. A maioria dos entrevistados apóia pesquisas que envolvam a análise de temas relacionados a transgenia, além de reconhecer a necessidade da rotulagem de alimentos transgênicos. Pode-se afirmar que o maior volume de investimentos em educação, entre outras iniciativas, poderia contribuir para a formação de professores e alunos, auxiliando-os a avaliar, criticamente, questões relativamente novas, como a transgenia. 


\title{
TRANSGENIC FOODS: THE OPINION OF SECONDARY SCHOOL TEACHER'S AND STUDENT'S OF THE NUTRITION AREA
}

\author{
Author: ANA CLÁUDIA CAYRES DE MENDONÇA \\ Adviser: Prof ${ }^{\mathrm{a}}$. $\mathrm{D}^{\text {ra }}$. MARINA VIEIRA DA SILVA
}

\section{SUMMARY}

The employment of transgenics organisms divides opinions and, therefore, it is cause of great controversy. In spite of the existence of vast list of publications that register the current benefits of the development of the transgenia, inquietude signs are verified on the part of the consumers with relationship to your employment in the food's production. Such behavior frequently elapses of the lack of clear information and emitted by agencies that enjoy the consumers' trust. This present study searched to know the level of information of teachers and students of technical courses in nutrition, maintained by public and located schools in different areas and municipal districts of São Paulo’s State. It was elaborated and adopted a questionnaire for the teachers, containing 33 descriptive and objective subjects, and one for the students, with 26 subjects, also with the involvement of subjects of the referred modalities. Both instruments referred to the interviewees' opinion in relation to the use of the transgenia. $\mathrm{He} / \mathrm{she} / \mathrm{you}$ fits to point out that, in these questionnaires, referring subjects were also included to the situation socioeconômica and these teachers' alimentary habits. For the analysis of the data the softwares were used Excel and the SAS ones. 
Of the teachers' total and chosen students that integrate the sample, 38\% and 69,3\%, respectively, agreed in participating in the research, being totaled 42 teachers and 277 interviewed students, originating from of 9 schools. Most of the teachers registered answers, considered pertinent, to the subjects related to the theme " transgenics ", although it was hoped the citations involved the use of more necessary terms, once the members of the sample were graduate, and, largely, postgraduates, in several kindred areas of the biological sciences. Most of the students also answered to referred them subjects, although, also, in a superficial way. The teachers' substantial portion (62\%) didn't know how to affirm transgenics food/product s are beneficial or malicious to the man, situation this already expected, by virtue of the shortage of information on the consequences that the consumption of these victuals can bring the man. Most of the interviewees supports researches that involve the analysis of related themes the transgenia, besides recognizing the need of the labelling of victuals transgenics. It can be affirmed that the largest volume of investments in education, among other initiatives, could contribute to the teachers' and students' formation aiding them to evaluate, critically, subjects relatively new, as the transgenics. 


\section{INTRODUÇÃO}

O emprego de transgênicos ou organismos geneticamente modificados na agricultura tem dividido opiniões e causado polêmica. Por um lado estão organizações nãogovernamentais, como a ambientalista Greenpeace ${ }^{1}$, que se posicionam contra o emprego desta tecnologia, alegando riscos ao meio ambiente e à saúde humana. Em situação oposta encontram-se grupos de produtores agrícolas que acreditam que a adoção da técnica possibilita maior produtividade, além de empresas, como é o caso da multinacional Monsanto, que desenvolve sementes transgênicas e têm interesse em conquistar e ampliar mercados para seus produtos. Também congrega esse grupo parcela da comunidade científica, que acredita que a transgenia possa melhorar a qualidade da produção de alimentos. Há, também, políticos e grupos da comunidade científica que, embora reconheçam os benefícios desta tecnologia, acreditam que seja necessária a implementação de expressivo volume de pesquisas, para a obtenção de comprovação científica, atestando que a técnica não traz riscos à saúde e ao meio ambiente.

Não se pode deixar de reconhecer alguns benefícios que esta tecnologia tem trazido à humanidade. Por exemplo, pode-se registrar que, antes de 1982, a insulina requerida pelos diabéticos era a extraída de animais (bois e porcos). O referido hormônio era semelhante à insulina humana, mas não idêntico o que causava, com freqüência, reações alérgicas. Naquele ano foi desenvolvido o primeiro produto derivado de um organismo transgênico: a insulina produzida por uma bactéria geneticamente modificada com a adoção de um gene humano. Obteve-se um hormônio igual ao produzido pelo organismo

\footnotetext{
${ }^{1}$ www.greenpeace.org / www.greenpeace.org.br
} 
humano, sem os efeitos colaterais, ou seja, os riscos de rejeição. A indústria farmacêutica, desde então, tem adotado a transgenia para aperfeiçoar a qualidade de seus produtos. Como um outro exemplo adicional de avanços nessa área pode ser citada a vacina contra a hepatite $B$, produzida com a proteína da superfície do vírus, que imuniza e impede a replicação do microrganismo e a conseqüente infecção. Esta vacina é produzida, desde 1997, pelo Instituto Butantã, localizado na cidade de São Paulo (SP).

Além das atividades envolvendo organismos transgênicos na área farmacêutica, há também a utilização destes na produção de enzimas, utilizadas na fabricação de bebidas, pães e laticínios, entre outros alimentos.

Na agricultura as sementes transgênicas, de acordo com as observações de produtores, apresentam maior produtividade em relação às sementes não transgênicas, por serem dotadas de características como resistência a herbicidas e resistência ao ataque de insetos. Algumas sementes são manipuladas de forma a originarem frutos que amadureçam com menor velocidade, como pode ser observado nas culturas de tomate (Borém \& Santos, 2003).

A produção, em nível comercial, de alimentos transgênicos que beneficiam diretamente os consumidores, os chamados transgênicos de segunda geração, encontrase em fase de planejamento. Como exemplos são observados o leite e iogurte transgênicos, dotados de proteínas, enzimas ou outros medicamentos produzidos por genes das bactérias lácticas, que contribuem para o tratamento do câncer do intestino ou diminuem as taxas de colesterol elevado. Em fase de pesquisas, podem ser citadas, também, batata e banana com vacina contra alguns tipos do papilomavírus humano (HPV) (Conselho de Informações sobre Biotecnologia, 2005).

Pode ser citado, também, o arroz-dourado (Golden rice), resultante da introdução simultânea de genes que possibilitam a expressão de conteúdo de beta-caroteno, que é convertido em vitamina A no organismo. Este produto foi desenvolvido em 1990 por pesquisadores alemães e suíços (Borém \& Costa, 2003). O arroz-dourado, segundo Azeredo (2003), é uma das alternativas para as regiões onde a deficiência de vitamina A constitui grave problema de saúde pública. 
Apesar do conjunto de benefícios, a aceitação dos transgênicos por uma parcela da população ainda é uma incógnita. Os alimentos geneticamente modificados possuem existência relativamente curta, integrando a alimentação humana há apenas 10 anos (Leite, 2000). Além do fato de serem iniciativas recentes, as existências de debates muitas vezes regados de conflitos, tem contribuído para gerar insegurança quanto aos seus riscos prováveis e hipotéticos, relacionados à saúde e ao meio ambiente. No entanto, cabe ressaltar que não se dispõe de tecnologia com risco zero e, portanto, o desafio é avaliar, por meio de método científico, a probabilidade de tais ocorrências.

Embora, até o presente momento, não haja nenhuma constatação de que produtos transgênicos tenham causado impacto negativo, a rejeição por estes alimentos parece não ser desprezível. Parece existir desconhecimento por parte do consumidor, além do fato de muitas vezes estarem consolidados pré-conceitos que podem manter expressiva distância do real conceito das novas tecnologias. O que também dificulta o esclarecimento dos consumidores é a influência exercida por pessoas de maior destaque na sociedade, que podem transmitir conceitos muitas vezes sem base científica ou ainda, revelar insegurança no que diz respeito às suas posições.

Por meio da constatação de que faltam esclarecimentos embasados em conhecimentos científicos e de que muitos conceitos não encontram sustentação científica, julgou-se pertinente à realização deste trabalho, tendo como objetivos:

- analisar a opinião dos consumidores que atuam na área de alimentos e nutrição em relação aos alimentos geneticamente modificados.

- avaliar a abrangência do conceito que os consumidores têm no tocante aos produtos transgênicos, as fontes de informação que contribuem para a formação de opinião e ainda, avaliar a disposição de pagar por um produto comprovadamente não transgênico.

Objetivou-se analisar a opinião de consumidores de cursos técnicos em nutrição por se tratar de uma área que envolve a formação de profissionais para atuarem na área de saúde e alimentos. Tais áreas são intensamente envolvidas a questão em destaque é a transgenia. 


\section{REVISÃO DE LITERATURA}

\subsection{Biotecnologia: Breve Histórico}

A biotecnologia, de acordo com o Novo dicionário Aurélio, é conceituada como sendo a “aplicação de processos biológicos à produção de materiais e substâncias para uso industrial, medicinal, farmacêutico, etc.” (Aurélio). A biotecnologia consiste, então, na aplicação em grande escala, ou na transferência para a indústria, dos avanços científicos e tecnológicos resultantes de pesquisas em ciências biológicas (Morais, 2005). A biotecnologia é um recurso utilizado há mais de 4000, quando os egípcios fabricavam vinhos e pães, por meio da fermentação. Durante os séculos seguintes muitas descobertas fizeram parte da história da Biotecnologia.

Em 1665, a existência das células foi comprovada por meio de experimentos do cientista inglês Robert Hooke, fato que desencadeou maior volume descobertas em biologia. Uma década depois, Anton van Leeuwenhoek inventou um microscópio com capacidade de ampliação de 270 vezes, o que permitiu a visualização de microorganismos. Em 1845, Matthias Schleiden e Theodore Schwann propuseram a teoria de que os organismos vivos são compostos de células. Estas constatações levaram os cientistas a questionarem as razões pelas quais os filhos tendem a apresentar características dos pais. A resposta a estes questionamentos surgiu em 1865, por meio de resultados dos experimentos baseados em cruzamentos de ervilhas com cores diferentes, realizados pelo monge Gregory Mendel, na República Tcheca. Estes experimentos derem início à ciência chamada genética - ciência que estuda a transmissão das características hereditárias e as unidades por elas responsáveis (genes). 
No início do século XX mais alguns estudos deram embasamento para que os cientistas concluíssem que as células continham substâncias responsáveis pela hereditariedade. Morgan identificou os cromossomos como conformações portadoras das unidades da hereditariedade (genes) (Borém \& Santos,2003). Com o estabelecimento da genética, alguns procedimentos como os melhoramentos de plantas puderem ser adotados. De acordo com Belém (2002), o melhoramento tem como base a existência da diversidade genética, ou seja, as diferença entre organismos da mesma espécie. A diversidade genética natural é originária das mutações e recombinações genéticas que ocorrem sem a intervenção humana. Os tipos variantes com características mais desejáveis, têm sido selecionados e mantidos no processo produtivo.

Em 1953, Watson \& Crick, dois cientistas da Universidade de Cambrigde, na Inglaterra, descreveram a estrutura helicoidal do DNA (Desoxirribonucleic Acid - Ácido Desoxirribonucléico), molécula fundamental de todos os seres vivos, portadora da informação genéticas. Eles demonstraram que a dupla hélice constituía-se de duas fitas pareadas, cada uma com sua seqüência de nucleotídeos (A, C, G ou T) complementar à outra: na posição em que havia um A na primeira, aparecia um $\mathrm{T}$ na segunda, e na posição em que havia um $\mathrm{G}$, aparecia um $\mathrm{C}$ e vice-versa. Um gene é a disposição destes nucleotídeos ao longo da molécula de DNA, podendo ter, como exemplo, a seqüência ATGCCGTTAGACTGAAA. Os genes diferem em tamanho (número de nucleotídeos A, C, G ou T) e seqüência (ordem destes nucleotídeos). Todos os seres vivos compartilham o mesmo código genético, que codifica e determina as proteínas dos animais, das plantas e dos microorganismos. Este código transforma a seqüência dos nucleotídeos A, C, G e T, presentes no DNA, em seqüência de aminoácidos, que constituem as proteínas, sendo que existem 20 diferentes aminoácidos. Portanto, cada proteína é derivada da transcrição e da tradução de um gene. O conjunto de vários genes em uma mesma molécula de DNA forma o cromossomo. Cada espécie tem um genoma próprio, composto de todos os seus genes organizados nos cromossomos, cujo número varia (Borém \& Santos, 2003).

A engenharia genética, que integra a biotecnologia moderna, consiste na modificação direta do DNA, de forma a alterar, precisamente, características específicas 
de um ser vivo ou, até mesmo, introduzir-lhes novos caracteres. O uso da biotecnologia moderna implica, de início, o conhecimento e o isolamento de seqüências de DNA que correspondem a genes responsáveis em conferir a característica desejada (Borém \& Santos, 2003). Quando isolado, o gene de interesse é incorporado, por meio da transformação gênica, no DNA do organismo alvo, resultando em um organismo geneticamente modificado, também conhecido como transgênico. A Tabela 1 apresenta alguns tópicos que distinguem a biotecnologia clássica e a biotecnologia moderna.

Tabela 1. Tópicos que distinguem biotecnologia clássica e biotecnologia moderna

\begin{tabular}{|c|c|}
\hline Biotecnologia clássica & Biotecnologia moderna \\
\hline $\begin{array}{l}\text { Transferência de genes realizada por meio } \\
\text { de cruzamento - Reprodução sexual }\end{array}$ & $\begin{array}{l}\text { Transferência de genes realizada por } \\
\text { meio de vetores }\end{array}$ \\
\hline $\begin{array}{l}\text { Possibilidade de modificações realizadas } \\
\text { em células reprodutoras }\end{array}$ & $\begin{array}{l}\text { Possibilidade de modificações realizadas } \\
\text { tanto em células reprodutoras quanto em } \\
\text { células somáticas }\end{array}$ \\
\hline $\begin{array}{l}\text { Trocas genéticas limitadas a indivíduos } \\
\text { da mesma espécie }\end{array}$ & $\begin{array}{l}\text { Trocas genéticas (intercâmbio gênico) } \\
\text { são permitido entre quaisquer seres vivos }\end{array}$ \\
\hline $\begin{array}{l}\text { Isolamento de gene específico não é } \\
\text { permitido }\end{array}$ & $\begin{array}{l}\text { Isolamento de um único gene } \\
\text { responsável pela característica específica } \\
\text { é possível }\end{array}$ \\
\hline Alteração aleatória & Alteração precisa \\
\hline
\end{tabular}
Fonte: Morais (2005).

A era da biotecnologia moderna teve início em 1973, por meio do desenvolvimento de estudos dos pesquisadores norte-americanos Herbert Boyer e Stanley Cohen. Os cientistas conseguiram reatar (recombinar) trechos de DNA de uma bactéria depois de terem incluído na seqüência um gene extraído do sapo. Tornara-se possível introduzir um gene de sapo numa bactéria e, com isso, induzir a bactéria a produzir uma proteína de sapo. Os referidos autores batizaram sua técnica "DNA recombinante”, mas, por influência da imprensa, que adotou outra nomenclatura para as estratégias de divulgação, a técnica se tornou mais conhecida como “engenharia genética” (Leite, 2000). 
Em julho de 1974, pesquisadores propuseram uma moratória voluntária para as pesquisas de engenharia genética. Foi convocada uma reunião internacional para discutir as implicações éticas e de segurança para a utilização da nova tecnologia (Leite, 2000).

Nesta reunião, conhecida pelo nome de Conferência de Asilomar, por ser realizada na cidade de Asilomar, Califórnia, ficou estabelecido que os experimentos poderiam ser retomados, desde que houvesse obediência aos métodos de contenções proporcionais ao risco presumido no tipo determinado de manipulação genética (Leite, 2000). Os conferencistas alertaram a comunidade científica quanto às questões de biossegurança inerentes à tecnologia do DNA recombinante. Desde então, a maioria dos países viu-se diante da necessidade de estabelecer legislação e regulamentações para as atividades que envolvessem a engenharia genética (Lajolo \& Nutti, 2002).

De 1974 a 1979, a biotecnologia sofreu restrições do público de vários países, mas os conflitos não foram tão intensos por não haver, fora dos ambientes de laboratórios, nenhum produto pronto para uso. O grau de preocupação diminuía conforme se consolidava um consenso sobre a necessidade de adoção ou exigência de estabelecimento de requisitos mínimos de segurança para os locais de experimentação que envolvessem organismos geneticamente modificados (OGM), como sistemas de filtragem do ar e pressão atmosférica negativa. No final dos anos 70, questionava-se, nos Estados Unidos, o rigor das regras introduzidas após o evento de Alisomar. As promessas de benefícios da biotecnologia começavam a preponderar sobre ameaças e riscos indeterminados (Leite, 2000).

Na Europa, grupos ambientalistas opuseram-se à adoção da referida técnica. No decorrer da década de 80 os países europeus começaram a aprovar, pouco a pouco, as próprias regulamentações para a engenharia genética. Tais iniciativas foram motivadas principalmente devido à ameaça de perda, mediante competição com os Estados Unidos, de complexos industriais da área química e farmacêutica (Leite, 2000).

No início dos anos 90, os Estados Unidos e países europeus dominavam tecnologias capazes de obter melhorias para o desempenho da agricultura. Na Europa, duas diretivas (219/90 e 220/90) estabeleciam, respectivamente, procedimentos para o trabalho em 
contenção e para liberação controlada no meio ambiente dos organismos geneticamente modificados.

Os alimentos geneticamente modificados foram comercializados pela primeira vez em 1994, nos Estados Unidos, com o lançamento do tomate Flavr Savr. Desde então, os OGMs vêm sendo cultivados em países das Américas, da Europa e da África. (Leite, 2000).

\subsection{Transgênicos}

Os organismos geneticamente modificados são organismos produzidos por meio da adoção de técnicas onde o material genético foi alterado de uma maneira que não ocorreria naturalmente. Os organismos transgênicos são aqueles que tiveram introduzido entre seus genes um novo gene ou fragmento de DNA, pela adoção do processo do DNA recombinante ou engenharia genética (Lajolo \& Nutti, 2003).

Por meio da chamada engenharia genética, pode-se transferir um gene de um organismo para outro, mesmo de espécies diferentes, sem o emprego dos processos normais de reprodução. O referido gene, ao ser transferido, confere suas propriedades ao organismo que o recebe (Leite, 2003).

As etapas envolvidas no processo de transgenia compreendem a localização do gene correspondente a uma característica desejada, a obtenção e clonagem ou multiplicação desse gene, a transformação da célula do organismo receptor e a seleção, regeneração da planta e fixação da característica desejada (Lajolo \& Nutti, 2003).

Geralmente, em sementes de alimentos, as características desejadas são: resistência a insetos, tolerância a herbicidas, produção de um determinado nutriente, amadurecimento retardado (Borém \& Costa , 2003). O milho Bt, por exemplo, é um transgênico que contém um gene de Bacillus thuringiensis, que confere resistência a larvas de insetos. Estes genes produzem na planta proteínas tóxicas para a larva do inseto. Outro exemplo é a soja. A soja convencional não é resistente ao herbicida glifosato, usado para controle 
de pragas, porque tem uma enzima (EPSPS'), que é inibida por ele, como o é a enzima de outras plantas. Ainda de acordo com os referidos autores, por meio das técnicas da engenharia genética foi possível obter o gene de uma enzima de uma bactéria e provocar uma alteração molecular correspondente a um aminoácido, tornando-a mais resistente ao herbicida. O gene modificado, o CP4EPSPS, foi introduzido no DNA da soja, gerando resistência ao glifosato por expressar uma enzima mais resistente e muito próxima estruturalmente da original .

\subsection{Segurança Alimentar e Nutricional : o caso dos transgênicos}

A Segurança Alimentar e Nutricional se apóia em dois pilares, a saber:

- o food security, utilizado para as análises que envolvem, entre outros aspectos, a disponibilidade quantitativa e os condicionantes do acesso da população aos alimentos. - o food safety, adotado para as abordagens relativas à qualidade do alimento. Um alimento de qualidade é aquele que apresenta a menor probabilidade de risco de causar doenças para o consumidor. Como exemplo, o alimento deve estar isento de microrganismos patogênicos ou toxinas, isento de resíduos de substâncias químicas (Lajolo \& Nutti, 2003).

Com relação aos alimentos transgênicos, os riscos potenciais tanto para os homens como para outros seres vivos (plantas, animais) estão associados a fatores como:

- novo DNA introduzido;

- produto de expressão desse DNA, a proteína;

- efeitos não intencionais, decorrentes da introdução no genoma e da expressão desse novo gene

- eventuais mutações

Lajolo \& Nutti (2003), consideram que a simples ingestão de DNA adicional não é considerada perigosa, já que o DNA é ingerido normalmente através de dietas. Entretanto, segundo os referidos autores, os produtos de expressão, as proteínas, podem

\footnotetext{
${ }^{1}$ 5-enolpiruvilchiquimato-3-fosfato sintase
} 
potencialmente ser tóxicos, ter ação antinutricional ou causar mudanças no valor nutricional do alimento. Ainda ressaltam que efeitos não-intencionais podem ocorrer. A inserção de um DNA nos cromossomos pode alterar a expressão de outros genes. Por exemplo, pode reativar genes silenciados por processos evolutivos ou em melhoramentos anteriores, os quais, ativados, passariam a produzir substâncias indesejáveis. Lajolo \& Nutti (2003) mencionam que as mudanças não intencionais podem ocorrer também em processos convencionais de melhoramento, até em maior proporção, devido à sua inespecificidade, o que faz com que, nos dois casos, sejam necessárias avaliações no tocante à segurança dos produtos resultantes.

A avaliação da segurança dos alimentos geneticamente modificados é a mesma adotada na avaliação da segurança dos aditivos, dos pesticidas, das contaminações químicas e microbiológicas em alimentos, havendo adaptações aos riscos potenciais específicos. Estes alimentos são submetidos a avaliações de segurança rigorosas, as quais não são impostas para a aprovação de alimentos convencionais, de acordo com Morais (2005). A avaliação de segurança é constituída por estudos moleculares, agronômicos, de composição toxicológica, de alergenicidade, de nutrição animal e de impacto ambiental (Morais, 2005).

A análise de risco, que envolve também o gerenciamento de risco e a comunicação de risco, consiste na busca de informações sobre um determinado perigo de forma a permitir a avaliação do risco envolvido e a adoção de medidas para eliminar ou controlar o perigo detectado. O gerenciamento de risco corresponde à busca de políticas e medidas de regulamentação e controle. No caso dos alimentos geneticamente modificados, correspondem à detecção, rastreabilidade e monitoramento póscomercialização. A comunicação de risco refere-se à informação da sociedade e á comunicação entre os segmentos envolvidos, como governo, população e institutos científicos, o que corresponde á rotulagem, serviços de informação ao consumidor e uso da mídia (Lajolo \& Nutti, 2003). De acordo com a Organização para Cooperação e Desenvolvimento Econômico (OCDE) - Organization for Economic Cooperation and Development (OECD), a avaliação de risco dos alimentos geneticamente modificados deve incluir: 
- identificação do organismo que foi geneticamente modificado;

- identificação dos produtos primários e secundários, incluindo a descrição das características do gene inserido;

- avaliação da segurança das novas substâncias no alimento receptor;

- avaliação de efeitos não-intencionais que podem ocorrer na composição do alimento, incluindo a avaliação de mudanças na concentração de nutrientes ou de toxinas naturais e demais componentes que mostraram alterações significantes no grau de concentração;

- avaliação da versão processada do alimento, por exemplo, se o consumo do mesmo for recomendado apenas após o cozimento;

- avaliação do potencial alergênico;

- avaliações relativas a tópicos que dizem respeito ao consumo, incluindo identificação da quantidade de seres humanos que consomem aquele alimento e quantos irão consumi-lo, e avaliação das diferenças que podem ocorrer entre o consumo de um produto geneticamente modificado ou de sua contraparte convencional.

Atualmente, os maiores riscos dos alimentos geneticamente modificados seriam os relacionados ao potencial alergênico e toxicológico e à resistência a antibióticos, de acordo com a OECD (1993).

A avaliação de alimentos e produtos geneticamente modificados utiliza-se do princípio da equivalência substancial, cujo conceito foi estabelecido devido à dificuldade de avaliação toxicológica de alimentos e da aplicação de normas usadas para aditivos químicos (OECD, 1993). Este conceito foi sugerido pela OECD em 1993 e posteriormente reconhecido pela FAO e OMS.

De acordo com a OECD, a equivalência substancial consiste na comparação de alimentos derivados da biotecnologia moderna com seus análogos convencionais. Se um alimento ou ingrediente alimentar derivado dos recentes avanços da biotecnologia for considerado substancialmente equivalente a um alimento ou ingrediente alimentar convencional, aquele alimento poderá ser considerado tão seguro quanto esse (OECD, 
1993). Lajolo \& Nutti (2003) observam que o conceito de equivalência substancial faz parte de uma estrutura de avaliação de segurança que se apóia na idéia de que alimentos já existentes podem servir como base para a comparação do alimento geneticamente modificado com o análogo convencional apropriado.

O estabelecimento da equivalência substancial, em se tratando de plantas geneticamente modificadas consiste, de acordo com Cockburn (2002) em:

a) avaliação nutricional do alimento geneticamente modificado - consiste em estudos para observar a resposta dos animais ao consumo do novo alimento, o que contribui para o julgamento da equivalência substancial;

b) comparação das características fenotípicas da planta geneticamente modificada com uma planta convencional - consiste em verificar se a nova planta apresenta o mesmo desempenho de seu equivalente tradicional em aspectos morfológicos e características agronômicas;

c) comparação analítica entre a composição da planta geneticamente modificada e a composição de análogos convencionais- avalia se a nova planta exibe a mesma composição, em micro e macronutrientes, apresentada pelo vegetal hospedeiro, sendo respeitadas as alterações intencionais introduzidas em um ou mais componentes;

d) avaliação da segurança: obtém-se o perfil de segurança da nova planta por meio de uma avaliação de perigos associados ao traço nela inserido e/ou de seus metabólitos intermediários e/ ou das características fenotípicas e de composição, com interesse em antinutrientes, toxinas e alérgenos. Se houver uma conclusão de que o novo produto é substancialmente equivalente à sua contraparte convencional, então os novos testes focalizarão a segurança da característica introduzida no produto.

O Departamento de Agricultura dos Estados Unidos e a Administração de Alimentos de Drogas do governo norte americano - United States Department of Agriculture (USDA) e Food and Drug Administration (FDA) adotam o princípio de equivalência substancial para avaliar produtos geneticamente modificados. 
Outro princípio muito empregado nas discussões envolvendo a segurança de organismos geneticamente modificados é o princípio da precaução. Trata-se de um princípio de gerenciamento de risco, originado na área de segurança ambiental e que extrapolou esse domínio.Foi estabelecido com vistas a prevenção de riscos ao meio ambiente e para impedir que contaminações especificadas prosseguissem, sem esperar por evidências conclusivas sobre os efeitos ambientais adversos (Lajolo \& Nutti, 2005). Entidades da União Européia, cuja maioria da população apresenta resistência à introdução de produtos geneticamente modificados em seus países, adota o princípio da precaução em suas avaliações, assim como parcela de cientistas e políticos brasileiros, contrários a liberação de produtos transgênicos no Brasil.

Antecedendo a liberação para a comercialização de qualquer planta geneticamente modificada, há necessidade de submetê-la a um expressivo conjunto de testes e análises, de forma a atestar sua segurança. Esta tem sido avaliada sistematicamente em diversos países (Azeredo, 2003).

Os órgãos responsáveis pela análise da segurança dos organismos geneticamente modificados, como a Comissão Técnica Nacional de Biossegurança (CTNBio) no Brasil; a Comissão Nacional de Assessoria em Biotecnologia Agropecuária (CONABia) na Argentina, United States Department of Agriculture (USDA) e Food and Drug Administration (FDA) nos EUA, European Food Safety Authority (EFSA) na Europa, Ministérios da Saúde e Meio Ambiente no Japão examinam a totalidade dos produtos geneticamente modificados quanto ao seu potencial alergênico e tóxico e quanto à sua digestibilidade. Além disso, a autorização para a sua liberação no mercado é precedida por análise da segurança ambiental. Mediante a existência de qualquer indício de falta de segurança, registra-se a “condenação” do produto (Borém \& Santos, 2003).

\subsection{Produção de transgênicos}

Cabe destacar que os principais produtos agrícolas convencionais mais cultivados no Brasil são a soja e milho 47,3 com milhões e 21,53 milhões de hectares, 
respectivamente, em 2004 (IBGE, 2004). A produção de soja no Brasil ocupa o segundo lugar no ranking mundial, com 120,5 milhões de toneladas plantadas, sendo superado apenas pelos Estados Unidos e seguido pela Argentina.

Segundo o Serviço Internacional para a Aquisição de Aplicações em Agrobiotecnologias - International Service for the Acquisition of Agri-biotech Applications (ISAAA), em 2004, a área global estimada de plantações geneticamente modificadas ocupava cerca de 81 milhões de hectares, 19,64\% adicionais comparados aos dados (67,7 milhões de hectares) de 2003, revelando continuidade de crescimento, identificada em oito anos consecutivos. A área aproximada de 81 milhões de hectares manteve cultivos, em 17 países, 8,25 milhões de agricultores. Em 2003, as sementes transgênicas foram adotadas, em 18 países, por sete milhões de agricultores.

Ainda de acordo com o ISAAA, entre 1996 e 2004, a área global de plantações transgênicas cresceu 48 vezes, de 1,7 milhão de hectares, em meados da década de 90, para 81 milhões de hectares, em 2004.

Os maiores produtores de transgênicos no mundo são os Estados Unidos, Argentina e Canadá. A Tabela 2, elaborada com dados do relatório do ISAAA, de 2004, reúne dados relativos aos seis principais produtores e suas respectivas produções, referentes aos anos de 2003 e 2004. 
Tabela 2. Principais países produtores de transgênicos, entre os anos 2003 e 2004

\begin{tabular}{|c|c|c|c|c|c|c|}
\hline Ano & \multicolumn{3}{|c|}{2003} & \multicolumn{3}{|c|}{2004} \\
\hline Classificação & País & Produção & $\%$ & País & Produção & $\%$ \\
\hline 1 & Estados & 42,8 & 63,0 & Estados & 47,6 & 58,8 \\
\hline & Unidos & & & Unidos & & \\
\hline 2 & Argentina & 13,9 & 21,0 & Argentina & 16,2 & 20,0 \\
\hline 3 & Canadá & 3,0 & 4,0 & Canadá & 5,4 & 6,67 \\
\hline 4 & Brasil & 3,0 & 4,0 & Brasil & 5,0 & 6,17 \\
\hline 5 & China & 2,8 & 4,0 & China & 1,7 & 2,10 \\
\hline 6 & $\begin{array}{l}\text { África do } \\
\text { Sul }\end{array}$ & 0,4 & 1,0 & Paraguai & 1,2 & 1,48 \\
\hline
\end{tabular}

Fonte: ISAAA (2005)

*em milhões de hectares

Atualmente a principal semente geneticamente modificada plantada no mundo é a soja, que ocupou, em 2004, 48,4 milhões de hectares (59,8\% da área total), seguida do milho, cujo plantio envolveu 19,3 milhões de hectares (23,8\% da área total), algodão, com 7,2 milhões de hectares (11\%) e canola, com 3,6 milhões (5\%) de hectares (ISAAA, 2005).

Ainda de acordo com estimativas do ISAAA (2005), em 2009 o plantio de transgênicos deverá atingir 100 milhões de hectares (ISAAA, 2005).

\subsection{Legislação de transgênicos}

No Brasil, o cultivo de transgênicos foi proibido até março de 2005. Apenas o cultivo e a comercialização da soja transgênica era permitido desde 2003, por meio das seguintes iniciativas: Medida Provisória 113, de março de 2003, Medida Provisória 131, de setembro de 2003, Lei $\mathrm{n}^{0}$ 10.814, 15 de dezembro de 2003, que estabelecia normas para o plantio e a comercialização da soja geneticamente modificada da safra de 2004, 
Medida Provisória 223, de outubro de 2004, da Lei $n^{0}$ 11.092, de 12 de janeiro de 2005, que estabelecia normas para o plantio e comercialização da produção de soja geneticamente modificada da safra de 2005.

Em março de 2005, a produção e a venda de transgênicos passou a ser regulamentada, posteriormente à aprovação e sanção do projeto de Lei de Biossegurança que, além de regulamentar e a produção e a venda de transgênicos, também regulamentou as pesquisas com células-tronco humanas. Instituições, empresas e agricultores que desejem realizar atividades com organismos geneticamente modificados devem, de acordo com o previsto na Lei de Biossegurança (Lei $n^{0} 11.105$ ) requerer prévia autorização junto à Comissão Técnica Nacional de Biossegurança (CTNBio) (Brasil, 2005).

\subsubsection{A polêmica da soja Roundup Ready ${ }^{\circledR}$}

Em 1998, a CTNBio emitiu parecer técnico favorável à liberação comercial da soja Roundup Ready ${ }^{\circledR}$ (RR) atestando a segurança alimentar e ambiental da soja. Neste período o Instituto de Defesa do Consumidor (IDEC) juntamente com o Greeenpeace, propuseram uma Ação Civil Pública, visando, dentre outros objetivos, exigir a realização de Estudo de Impacto Ambiental (EIA). Em decorrência das referidas iniciativas, desde 1998, havia a proibição do cultivo comercial de transgênicos. Entretanto, os sojicultores, em grande maioria oriundos do Rio Grande do Sul, decidiram cultivar a soja transgênica, conhecida como "soja Maradona”, trazida de forma clandestina da Argentina. Em março de 2003, foi colhida uma safra, avaliada em 1 bilhão de reais, cabendo ao governo federal a responsabilidade pela decisão de como proceder em relação à soja ilegal. Por meio da Medida Provisória 113, de 26 de março de 2003, o presidente Luiz Inácio Lula da Silva autorizou a comercialização da soja, no mercado interno (Brasil, 2003 c). Por meio da referida medida provisória, foi garantida a venda da soja transgênica da referida safra, até 31 de janeiro de 2004. As normas para a 
comercialização da soja da safra de 2003 estão registradas na Lei n ${ }^{0} 10.688$, de 13 de junho de 2003 (Brasil, 2004b).

Em 25 de setembro de 2003 o governo autorizou, por meio da Medida Provisória 131, o plantio da soja transgênica, apenas para a safra 2003/04, (Brasil, 2003e). Em 14 de outubro de 2004, visto que a Lei de Biossegurança ainda não havia sido aprovada, foi editada nova medida provisória, a $M P n^{0}$ 223, que autorizava o plantio de soja transgênica para a safra 2004/05.

\subsection{2 Órgão Regulador}

Os Organismos Geneticamente Modificados são avaliados, no Brasil, pela Comissão Técnica Nacional de Biossegurança, a CTNBio, órgão integrante do Ministério da Ciência e Tecnologia, que, de acordo com a Lei de Biossegurança (lei $n^{0}$ 11.105) tem competência para liberar o plantio e a comercialização de transgênicos. A CTNBio foi criada por meio da Lei n ${ }^{0}$ 8.974, de cinco de janeiro de 1995.

A finalidade desta comissão multidisciplinar é a de prestar apoio técnico e de assessoramento ao Governo federal na formulação, atualização e implementação da Política Nacional de Biossegurança relativa aos OGMs e seus derivados. A comissão objetiva, também, a elaboração de normas técnicas de segurança e a formação de pareceres técnicos referentes à proteção da saúde humana, dos organismos vivos e do meio ambiente, para atividades que envolvam a construção, experimentação, cultivo, manipulação, transporte, comercialização, consumo, armazenamento, liberação e descarte de OGM e derivados. Atualmente, a CTNBio é composta por 27 representantes da comunidade científica, com notório e reconhecido conhecimento em biotecnologia e biossegurança, sendo:

- 12 especialistas - três da área de saúde humana; três da área animal; três da área vegetal; de da área de meio ambiente;

- um representante da Secretaria Especial de Aqüicultura e Pesca da vinculada a Presidência da República e um representante de cada um dos seguintes Ministérios: Ciência e Tecnologia; Agricultura, Pecuária e 
Abastecimento; Saúde; Meio Ambiente; Desenvolvimento Agrário; Desenvolvimento, Indústria e Comércio Exterior, Defesa; Relações Exteriores;

- um especialista em cada uma das seguintes áreas: defesa do consumidor, saúde, meio ambiente, biotecnologia, agricultura familiar, saúde do trabalhador, sendo todos estes devendo ser indicados, respectivamente, pelos ministros da Justiça. Saúde, Meio Ambiente, Agricultura, Pecuária e Abastecimento; Desenvolvimento Agrário; Trabalho e Emprego.

Para que uma planta geneticamente modificada seja analisada e em seguida seja elaborado o parecer técnico conclusivo da CTNBio, a empresa responsável deverá apresentar relatório com dados que contemplem as questões apresentadas, podendo a CTNBio solicitar ainda informações adicionais.

De acordo com a Lei de Biossegurança, aprovada em março de 2005, no caso de parecer da CTNBio ser contestado pelo governo, governo, a decisão final caberá ao Conselho Nacional de Biossegurança, criado por meio desta Lei, integrado por 10 ministros e presidido pelo Chefe da Casa Civil da Presidência da República (Brasil, 2005).

\subsubsection{Normas de Rotulagem}

Em vários países a legislação para a rotulagem de alimentos estabelece limites permissíveis de OGMs. Dessa maneira, alimentos que contêm ingredientes geneticamente modificados em níveis acima do permitido devem ser rotulados como “geneticamente modificados” (Lajolo \& Nutti 2000).

A rotulagem pode não ser requerida para alimentos que não contêm quantidades mensuráveis da nova proteína ou DNA, como é o caso de ingredientes alimentares refinados (por exemplo, sacarose e óleos vegetais), uma vez que qualquer material genético e proteína que possam estar presentes são “destruídos” e removidos durante o processo de refino. Desse modo, o produto final que integra a composição do alimento 
não é, em si, modificado e, portanto, não pode ser distinguido daquele produzido por meio de meios convencionais (Donaldson \& May, 1999).

No Brasil, por meio do Decreto $n^{0} 4.680$, de 24 de abril de 2003, "na comercialização de alimentos e ingredientes alimentares destinados ao consumo humano ou animal que contenham ou sejam produzidos a partir de organismos geneticamente modificados, com presença de $1 \%$ do produto, o consumidor deverá ser informado da natureza transgênica desse produto". De acordo com o referido decreto, "tanto nos produtos embalados como nos vendidos a granel ou in natura, o rótulo da embalagem ou do recipiente em que estão contidos deverá constar, em destaque, no painel principal e em conjunto com o símbolo a ser definido mediante ato do Ministério da Justiça, uma das seguintes expressões, dependendo do caso” (nome do produto) transgênico”, “contém (nome do ingrediente ou ingredientes) transgênicos(s)” ou "produto produzido a partir de (nome do produto) transgênico”. Em 17 de dezembro de 2003, foi publicada, no Diário Oficial da União, a portaria MJ 2658, que registrou padrões para a rotulagem de transgênicos no País. Esta portaria entrou em vigor no dia primeiro de abril de 2004. De acordo com as normas desta, todos os fabricantes de alimentos que contenham material transgênico, deverão, compulsoriamente imprimir nos rótulos um símbolo padrão, sugerido pelo Departamento de Proteção e Defesa do Consumidor (DPDC), do Ministério da Justiça, e submetido à consulta pública durante o mês de outubro de 2003, para que pessoas físicas e jurídicas pudessem oferecer suas contribuições (Brasil, 2003).

O símbolo, que objetiva facilitar a identificação, por parte do consumidor, de alimentos produzidos a partir de transgênicos, consta de uma letra "T" inserida em um triângulo eqüilátero, e deverá de ser usado nas embalagens de produtos destinados ao consumo humano e animal. Para facilitar a visualização, o símbolo, nas embalagens coloridas, deverá ter as bordas do triângulo em preto e o fundo amarelo. A letra “T” será preta (Figura 1). Nos rótulos impressos em preto e branco o as bordas do triângulo deverão ser pretas e o fundo, branco, conforme ilustrado na Figura 2. 


\section{个}

Figura 1- Símbolo para rótulos impressos embalagens coloridas

Fonte:Ministério da Justiça (2004)

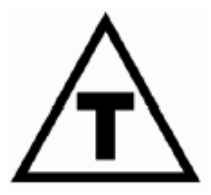

Figura 2 - Símbolo para rótulos impressos em preto e branco

Fonte: Ministério da Justiça (2004)

A fiscalização de produtos transgênicos, quanto à rotulagem, transporte e armazenamento, cabe à Agência Nacional de Vigilância Sanitária (Anvisa), órgão vinculado ao Ministério da Saúde, e ao Ministério da Agricultura.

\subsection{Transgênicos: Europa e Estados Unidos}

Os Estados Unidos são um país pioneiro tanto na produção quanto na regulamentação e consumo de alimentos geneticamente modificados. São os maiores detentores das aplicações comerciais da biotecnologia moderna. São, também, os maiores exportadores de culturas geneticamente modificadas e regulamentam a biotecnologia de forma distinta do modelo regulatório adotado pela Europa. De acordo com Morais (2005), a estrutura reguladora norte-americana se baseia na avaliação do produto final e não nos processos de produção dos alimentos. Autoridades Governamentais dos EUA vêem as novas técnicas de modificação genética como uma extensão dos demais processos tecnológicos, considerando os novos produtos 
desenvolvidos por esta técnica como análogos, ou equivalentes aos já existentes, no que diz respeito aos procedimentos de avaliação de segurança, como afirmado em tópico anterior. Neste país, inexiste qualquer obrigatoriedade para a rotulagem de alimentos geneticamente modificados. O Food and Drug Administration (FDA) registra argumentos, como por exemplo: “se alimentos geneticamente modificados são substancialmente equivalentes aos seus análogos convencionais, nenhum tipo de rotulagem é requerida, a não ser nos casos em que o conteúdo nutricional tenha sido alterado ou o produto contenha alérgenos conhecidos (Lajolo \& Nutti, 2003). Rotula-se, portanto, o produto com base em sua composição e não com base no processo de obtenção".

Na União Européia, as exigências para avaliações de risco de OGMs relativas à saúde humana e ao meio ambiente foram compiladas na Diretiva $n^{0}$ 220/90/CEE, de 23 de abril de 1990 e são similares às estabelecidas pelos órgãos da agricultura, saúde e meio ambiente dos Estados Unidos. Entretanto, o sistema europeu de avaliação de risco estabelece que os requisitos e informações devem ser apresentados pelo requerente de forma compulsória, diferindo do procedimento adotado pelos EUA, onde o governo avalia o risco com base nas informações que o solicitante considera pertinentes. Esta diretiva sofreu algumas alterações e foi revogada pela Diretiva $n^{0} 18 / 2001$, que entrou em vigor em 17 de outubro de 2002 (Morais, 2005).

A legislação européia referente à avaliação de segurança e comercialização de OGMs é baseada na Diretiva $n^{0} 18 / 2001$, sendo complementada por alguns regulamentos. De acordo com esta diretiva, os Estados-Membros são incumbidos de tomar todas as medidas necessárias para evitar efeitos negativos à saúde humana e ao meio ambiente.

De acordo com o previsto na diretiva, antes de se proceder a uma liberação planejada de OGM, uma notificação deve ser apresentada à autoridade competente do Estado-Membro em cujo território deverá ter lugar a liberação. Antecedendo a manifestação da autoridade nacional ao notificante, é necessário que a Comissão Européia receba um resumo do conteúdo da notificação (Morais, 2001). 
A aprovação do produto depende dos riscos que este representa à saúde humana e animal, conforme avaliação de risco realizada por autoridade competente, no caso a European Food Authority (EFA). Este processo tem duração de seis meses e, após este período, pode haver ainda a análise do Parlamento Europeu, que pode ser discordante ao posicionamento da EFA. (Souza, 2003).

Na União Européia, até julho de 2003, 18 variedades de alimentos geneticamente modificadas foram aprovadas pela EFA e pelo Parlamento Europeu. As referidas variedades eram rotuladas e comercializadas normalmente. A legislação preconiza que alimentos que contêm uma porcentagem superior a 1\% de OGMs ou de seus derivados devam ser rotulados. No início do mês de julho de 2003, o Parlamento Europeu liberou outras variedades de OGMs, desde que recebesse rotulagem todo e qualquer alimento que incluísse transgênicos em sua composição, mesmo que não apresente nenhum traço da proteína sintetizada pelo gene introduzido no organismo. Por exemplo, o óleo de soja não contém nenhuma proteína, ou seja, não contém a proteína que confere à planta sua resistência a pesticidas, mas deverá registrar no rótulo a frase "Produzido a partir de transgênicos”. Para produtos importados, a União Européia passou a exigir que,no caso do produto apresentar mais do que $0,9 \%$ de transgênicos deveria ser rotulado, com o pertinente registro da informação (Souza, 2003).

Nos Estados Unidos, inexiste qualquer obrigatoriedade para a rotulagem de alimentos geneticamente modificados, como já comentado no tópico anterior. O Food and Drug Administration (FDA) registra argumentos, como por exemplo: "se alimentos geneticamente modificados são substancialmente equivalentes aos seus análogos convencionais, nenhum tipo de rotulagem é requerida, a não ser nos casos em que o conteúdo nutricional tenha sido alterado ou o produto contenha alérgenos conhecidos” (Lajolo \& Nutti, 2003). Portanto, no referido País, é efetuada a rotulagem do produto com base em sua composição e não considerando o processo de obtenção/produção. 


\subsection{Transgênicos: posição de organismos internacionais e nacionais}

A World Health Organization (WHO), Organização Mundial da Saúde (OMS), órgão da (ONU) - Organização das Nações Unidas (ONU) para a saúde divulgou, em 23 de junho de 2005, um relatório, na qual afirmava que os transgênicos poderiam ser benéficos, tanto para a agricultura quanto para a saúde. De acordo com o relatório, de nome Modern food biotechnology, human helth and development (Moderna biotecnologia de alimentos, saúde humana e desenvolvimento), os transgênicos podem aumentar as safras e a qualidade dos alimentos, o que melhoraria a saúde e a nutrição das populações, além de trazer maior lucro para agricultores e indústrias. Entretanto, o relatório contém ressalvas: como alguns genes introduzidos nos alimentos são diferentes dos genes das cadeias naturais, os efeitos potenciais sobre a saúde e meio ambiente devem ser sempre avaliados antes do cultivo e comercialização. O diretor do Departamento de Segurança Alimentar da OMS, Jorgen Schlundt, explica que “não há dados que sugiram que os alimentos transgênicos no mercado não sejam seguros, mas este fato não é o mesmo que dizer que os alimentos transgênicos no futuro serão automaticamente seguros” (WHO, 2005) e também ressalta que nenhum alimento, transgênico ou natural, é 100\% seguro, e como exemplo cita as cinco mil pessoas que, anualmente, morrem, nos Estados Unidos, anualmente, em decorrência de infecções alimentares causadas por bactérias patogênicas, como por exemplo a Salmonella.

O relatório registra a crença da OMS que os alimentos transgênicos possam contribuir para a diminuição dos índices de fome e desnutrição no mundo, citando que esses elementos podem ser importantes para atender às futuras demandas alimentares, ampliando a oferta de vitaminas e ferro para populações mais pobres. O texto registra afirmações do tipo "produção de propriedades nutritivas em lavouras consumidas pelos pobres pode reduzir a incidência das doenças em países em desenvolvimento”, citando também o benefício trazido pelos transgênicos decorrente da diminuição do uso de agrotóxicos. 


\subsection{O comportamento do consumidor}

A aceitação de novas tecnologias por parte dos consumidores freqüentemente é difícil e demorada. Quando a vacina contra a varíola foi desenvolvida, no fim do século XVIII, houve expressiva rejeição, pois, além de ser uma nova tecnologia, o procedimento de infectar pessoas sadias, com material coletado de pústulas de gado doente não gerava qualquer confiança (Borém \& Costa, 2003). Em meados dos anos 70, as pesquisas para a concepção de bebês em provetas foram duramente criticadas por expressivos segmentos da sociedade, pela igreja e até por membros da comunidade científica. Comportamento similar tem sido observado, quando se discute a utilização, especialmente para a alimentação humana, dos produtos transgênicos. A rejeição é grande, mas os consumidores devem procurar informar-se sobre as novas tecnologias.

De acordo com Morais (2005), a mera existência de discussões sobre novos riscos pode agravar as preocupações do público. As preocupações com o risco se baseiam mais nos sentimentos que na racionalidade. Ainda observa-se que a chamada massa de pânico consiste em um tipo de ação bastante utilizado por regimes totalitários, como o nazismo, que adotava slogans como "Levanta, Alemanha”, para clamar o povo a lutar contra os que eram classificados como inimigos, que ameaçavam a nação alemã. No Brasil existem campanhas, como as lideradas pela organização não-governamental Greenpeace e o Instituto de Defesa do Consumidor (IDEC) que adotam alguns slogans, como "Por um Brasil Livre de Transgênicos”, que podem contribuir para que os consumidores sintam-se temerosos em relação a esta tecnologia².

A informação é um direito do consumidor, explicitamente registrado no Código de Defesa do Consumidor. O artigo $6^{\circ}$, Incisos I, II, III, IV e VII, Capítulo III do Código garante, ao consumidor, "a proteção da vida, saúde e segurança contra os riscos provocados por práticas no fornecimento de produtos e serviços considerados perigosos ou nocivos; a educação sobre o consumo adequado dos produtos e serviços; a informação adequada e clara sobre especificação correta de quantidade, características, composição, qualidade e preço; a proteção contra a publicidade enganosa e abusiva; a

\footnotetext{
${ }^{2}$ www.greenpeace.org.br e www.idec.org.br
} 
proteção jurídica, administrativa e técnica aos necessitados, com vistas à prevenção ou reparação de danos patrimoniais e morais” (Código de Defesa do Consumidor, 1990).

Para que novas tecnologias sejam aceitas e adotadas pela sociedade é necessário o conhecimento e confiança, especialmente na posição das autoridades sanitárias, que precisam desenvolver credibilidade.

O Instituto de Defesa do Consumidor (IDEC) e o Conselho de Informações sobre Biotecnologia (CIB), em seus sites, na rede mundial de computadores, reúnem contribuições na forma de informações sobre biotecnologia. Entretanto, verifica-se a necessidade dos consumidores serem melhor informados sobre questões referentes a biotecnologia, visto que a desinformação ainda é grande, além da reconhecida necessidade de ampliação dos meios de acesso às informações.

Há registros de que expressiva parcela de consumidores brasileiros não sabe registrar , de maneira correta, o conceito de "alimentos transgênicos". No entanto, esses consumidores assumem posições favoráveis ou contrárias sem um acervo minimamente adequado de informações e análises. Segundo pesquisa realizada em dezembro de 2002 pelo Instituto Brasileiro de Opinião Pública e Estatística (IBOPE), baseada em amostragem envolvendo 2000 pessoas, 65\% da população brasileira manifestava-se contra os alimentos transgênicos e 61 \% das pessoas não souberam registrar o conceito. Ilustra a situação, relativa à dificuldade a existência de registros tais como: “já li que causa câncer”, “eu sei que é uma coisa clonada que não vai fazer bem”, “acho que é como injetar algo em uma laranjeira” (IBOPE, 2003).

De acordo com Oda \& Soares (2001), a aceitabilidade pública está ligada a clara demonstração dos reais benefícios dessa tecnologia para a sociedade em questão. Para a situação americana, onde a exportação desses produtos agrícolas representa forte componente na economia do país, é justificável a maior aceitabilidade, já que sob o ponto de vista da análise de riscos os órgãos governamentais consideram esses produtos geneticamente modificados (milho e soja) equivalentes a seus homólogos convencionais. Para a sociedade européia, entretanto, a introdução desses produtos geneticamente modificados (milho e soja) não representa vantagens adicionais para o consumidor, quer 
seja pelo aspecto qualitativo ou pelo aspecto econômico. Portanto, não são identificadas vantagens da introdução dessa tecnologia na produção de alimentos para esses países.

Muitas das informações errôneas, identificadas por pesquisas, podem ser transmitidas por pessoas que exercem influência em seu meio, como profissionais da área de saúde, da educação, comunicação e até ainda por autoridades políticas e, eventualmente, algumas celebridades. 


\section{MATERIAL E MÉTODOS}

\subsection{População de estudo}

Para a realização da pesquisa, foi definida uma amostra dos professores e alunos dos cursos técnicos em nutrição, cujas escolas vinculam-se ao Centro Estadual de Educação Tecnológica Paula Souza. Foram estabelecidos contatos com a Coordenação de Ensino Técnico do Centro Paula Souza, situada na cidade de São Paulo, visando à identificação dos municípios paulistas que mantinham as unidades de ensino e, também, o número de professores e alunos vinculados a cada uma dessas escolas. O Quadro 1 apresentado a seguir reúne as informações relativas à vinculação dos docentes e discentes, de acordo com os municípios onde se situam as unidades de ensino.

Mediante contatos prévios estabelecidos com os dirigentes das unidades, foi possível obter a aquiescência de parcela dos diretores para a realização da pesquisa.

Do total de 21 escolas atuantes no Estado de São Paulo que implementam o curso técnico em nutrição, foi possível desenvolver a pesquisa em 9 unidades que mantinham 116 professores e 400 alunos. Deste conjunto, 42 professores (36,2\%) e 277 alunos $(69,3 \%)$ concordaram em participar da pesquisa. ${ }^{1}$

\footnotetext{
${ }^{1}$ A pesquisa foi aprovada pelo Comitê de Ética em Pesquisa (CEP) da Faculdade de Odontologia de Piracicaba - FOP, vinculada à UNICAMP (protocolo 088/2004).
} 


\begin{tabular}{|c|c|c|c|}
\hline Município & Região Administrativa (*) & $\begin{array}{c}\mathrm{N}^{0} \text { de } \\
\text { professores }\end{array}$ & $\begin{array}{l}\mathrm{N}^{0} \text { de } \\
\text { alunos }\end{array}$ \\
\hline Piracicaba & \multirow[t]{5}{*}{ Região Administrativa de Campinas } & 7 & 30 \\
\hline Limeira & & 7 & 30 \\
\hline Hortolândia & & 4 & 30 \\
\hline Casa Branca & & 5 & 30 \\
\hline Araras & & 3 & 30 \\
\hline Pindamonhangaba & \multirow{2}{*}{$\begin{array}{l}\text { Região Administrativa de São José dos } \\
\text { Campos }\end{array}$} & 6 & 20 \\
\hline Cruzeiro & & 5 & 20 \\
\hline Sorocaba & \multirow[t]{2}{*}{ Região Administrativa de Sorocaba } & 10 & 40 \\
\hline Tatuí & & 4 & 30 \\
\hline Santos & $\begin{array}{c}\text { Região Metropolitana da Baixada } \\
\text { Santista }\end{array}$ & 10 & 60 \\
\hline São Paulo & \multirow[t]{4}{*}{ Região Metropolitana de São Paulo } & 48 & 80 \\
\hline Jundiaí & & 2 & 30 \\
\hline Santo André & & 3 & 30 \\
\hline Mogi das Cruzes & & 8 & 30 \\
\hline Ribeirão Preto & \multirow[t]{2}{*}{ Região Norte do Estado } & 14 & 60 \\
\hline Barretos & & 10 & 30 \\
\hline Botucatu & Região Oeste do Estado & 10 & 30 \\
\hline Araraquara & \multirow[t]{2}{*}{ Região Central $^{*}$} & 8 & 40 \\
\hline Jaú & & 5 & 30 \\
\hline TOTAL & 7 & 157 & 680 \\
\hline
\end{tabular}

Quadro1- Características dos municípios e número de professores e alunos que atuam nas unidades de Ensino do Centro de Educação Tecnológica Paula Souza. São Paulo, 2004

(*) De acordo com a Fundação Sistema Estadual de Análise de Dados (Seade - 2004), o Estado de São Paulo é dividido em sete regiões administrativas. A Seade não atribui denominação à região central. 
Cabe destacar que professores e alunos foram esclarecidos sobre os objetivos e motivação da pesquisa mediante a apresentação do Termo de Consentimento Livre e Esclarecido (ANEXO A), contendo um resumo do projeto e esclarecimentos sobre a metodologia a ser empregada e as formas de divulgação dos resultados”. Foram adotados questionários (ANEXO B, ANEXO C) contendo questões descritivas e objetivas, que foi auto- aplicado. Os participantes receberam auxílio apenas para dirimir dúvidas no tocante à interpretação das questões. Cada integrante da pesquisa respondeu, no âmbito das unidades de ensino, às questões em, aproximadamente, 30 minutos, no horário do intervalo das aulas. O questionário foi respondido pelos alunos durante a jornada das aulas, por uma parcela do tempo cedido pelos professores.

Cabe registrar que os questionários foram previamente testados, com envolvimento de grupo de indivíduos que não participaram da amostra final da presente pesquisa.

A seguir, são apresentadas as características relativas aos municípios, que abrigam as unidades de ensino e o número de professores e alunos participantes que se vinculam às escolas. 


\begin{tabular}{|c|c|c|c|c|}
\hline $\begin{array}{l}\text { Município onde se } \\
\text { localiza a Unidade } \\
\text { de Ensino }\end{array}$ & \begin{tabular}{|l|} 
Total de \\
Professores
\end{tabular} & $\begin{array}{l}\mathrm{N}^{0} \text { de professores } \\
\text { participantes da } \\
\text { pesquisa }\end{array}$ & $\begin{array}{l}\text { Total de } \\
\text { Alunos }\end{array}$ & $\begin{array}{l}\text { Número de alunos } \\
\text { participantes da } \\
\text { pesquisa }\end{array}$ \\
\hline Araraquara & 8 & $5[11,9]$ & 40 & $22[7,9]$ \\
\hline Botucatu & 10 & $3[7,1]$ & 30 & $15[5,4]$ \\
\hline Jaú & 5 & $4[9,5]$ & 30 & $26[9,4]$ \\
\hline Piracicaba & 7 & $5[11,9]$ & 30 & $23[8,3]$ \\
\hline Ribeirão Preto & $\overline{14}$ & $3[7,1]$ & 60 & $43[15,5]$ \\
\hline São Paulo & 48 & $6[14,3]$ & 80 & $64[23,1]$ \\
\hline Santos & 10 & $5[11,9]$ & 60 & $32[11,6]$ \\
\hline Sorocaba & 10 & $8[19,0]$ & 40 & $26[9,4]$ \\
\hline Tatuí & 4 & $3[7,1]$ & 30 & $26[9,4]$ \\
\hline TOTAL & 116 & $42(36,2)$ & 400 & $277(69,2)$ \\
\hline
\end{tabular}

Quadro 2 - Distribuição dos professores e alunos dos cursos Técnicos em Nutrição das unidades de ensino pertencentes ao Centro Paula Souza, integrantes da pesquisa, de acordo com o município onde se localiza a unidade de ensino

São Paulo, 2004

Nota: os números entre chaves são os percentuais em relação ao total de professores $(n=42)$ e alunos ( $n=277)$ da amostra . O número entre parênteses é a percentagem em relação ao total de professores que lecionam nas unidades de ensino que integram a rede $(n=116)$ e ao total de alunos que estudam na rede $(n=400)$.

\subsection{Análise de Dados}

Para a construção do banco de dados foi adotado o software Excel.

As análises estatísticas foram elaboradas utilizando-se o software SAS (1998). 


\section{$4 \quad$ RESULTADOS E DISCUSSÃO}

\subsection{Caracterização dos participantes da pesquisa: aspectos socioeconômicos, estilo de vida e atitudes relativas à aquisição e consumo de alimentos}

Cabe lembrar que, conforme descrito na seção referente à metodologia, foram entrevistados 42 professores e 277 alunos. A maioria dos participantes da pesquisa é do gênero feminino (95,2\% dos professores e 94,6\% dos alunos). No tocante à idade, cumpre destacar que 39 e 23 anos entre os alunos foram as médias obtidas entre professores e alunos, respectivamente.

A maioria dos alunos entrevistados, 84,1\% possuía idade entre 16 e 30 anos no ano em que a pesquisa foi realizada. Dos professores, 20\% possuíam idade entre 23 e 28 anos; 55\% entre 32 e 44 anos e $25 \%$, entre 46 e 54 anos.

Em relação à formação superior, 71,4\% dos professores são graduados em Nutrição, 7,1\% em Engenharia de Alimentos, 4,8\% em Ciências Biológicas, 4,8\% em Hotelaria e 2,4\% em Engenharia Agronômica. A graduação não foi informada por 4,8\% dos professores e apenas 2,4\% dos entrevistados são graduados em dois cursos superiores. Nesta pesquisa pôde ser constatado que 2,4\% dos professores não possuem formação superior, possuindo apenas o título de Técnico em Nutrição e Dietética. Dos entrevistados, 69\% detém o título de pós-graduado e, destes, 37,9 \% , obtiveram o título de mestre (curso de pós-graduação strictu sensu), 55,2 \% , cursaram a especialização (lato sensu) e 7,7\%, informaram que tiveram acesso às duas modalidade de pósgraduação (strictu-sensu e lato- sensu).

Os professores foram questionados se exerciam outra atividade além de ministrar aulas nos cursos técnicos considerados na pesquisa. Dentre os resultados, observou-se 
que 26,2\% não exercem outra atividade, 23,8\% também atuam, como docentes, em outras escolas, $21,4 \%$ trabalham em serviços de alimentação (restaurantes industriais e hospitais) ou em agência de vigilância sanitária, 14,3\% exercem atividades em consultório e 9,5\% identificaram-se como empresários. Além de ministrarem aulas, 4,8\% dos entrevistados são coordenadores do Curso Técnico em Nutrição e Dietética. Merecem atenção os dados referentes a atividades dos entrevistados fora da escola técnica (Centro Estadual de Educação Tecnológica Paula Souza). Dos entrevistados, 73,8\% exercem atividades além das aulas ministradas na unidade de ensino técnico escola técnica, demonstrando que os professores não se dedicam exclusivamente às aulas da escola técnico.

Submetidos ao mesmo questionamento, isto é, se exercem outra atividade, os alunos informaram que 35,1\% deles não têm outra atividade, 16,6\% trabalham em setores distintos da área de alimentação/saúde, 6,9\% trabalha na área de alimentação/saúde (confeiteiro, cozinheira, estoquista, garçom) e 5,1\% afirmaram que trabalham, mas não especificaram a área de atuação. Atividades como freqüências a outro curso (magistério, ensino médio) e estágio foram citadas por $26 \%$ dos alunos. Apenas 1,1\% dos entrevistados, identificaram-se como sendo “donas de casa”. De forma sintética, pode-se dizer que a maioria dos alunos entrevistados (55,7\%) dos alunos entrevistados têm outra atividade, enquanto 35,1\% assumem não ter outra atividade, e 9,2\% dos alunos não responderam à questão.

Com relação à renda dos entrevistados, foram solicitadas informações relativas à renda pessoal e familiar dos professores e a renda familiar dos alunos. Os resultados obtidos podem ser observados na Tabela 3. 
Tabela 3. Distribuição dos professores e alunos integrantes da pesquisa de acordo com a os estratos de rendimento pessoal e familiar (em salários mínimos). São Paulo, 2004

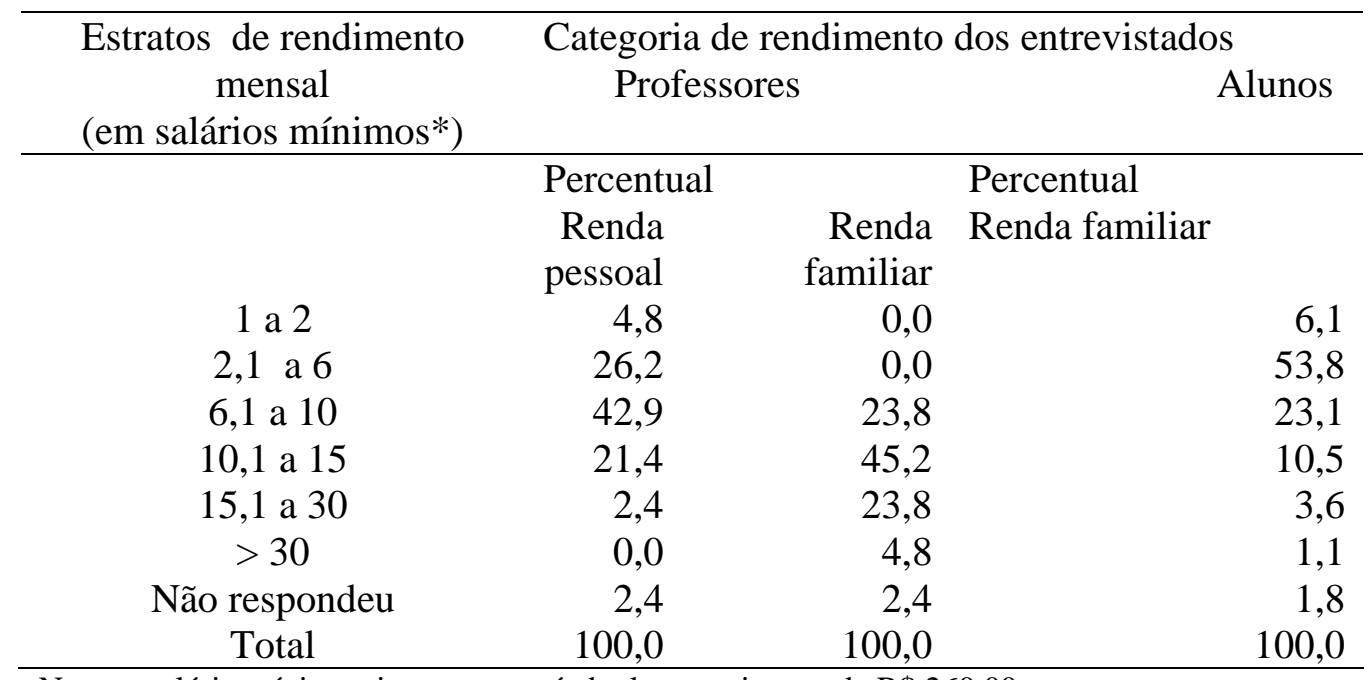

Nota: o salário mínimo vigente no período da pesquisa era de R \$ 260,00.

De acordo com a tabela 1, parcela expressiva dos professores (42,9\%) possui renda pessoal que varia entre 6,1 a 10 salários mínimos. Reduzida parcela dos entrevistados, 2,4\%, tem rendimento entre 15,1 e 30 salários mínimos e nenhum entrevistado possui renda pessoal que supera 30 salários mínimos. Quando são levados em consideração os rendimentos familiares dos entrevistados, verifica-se predomínio de famílias (45,2\%) cujos rendimentos variam entre 11 e 15 salários mínimos, valores classificados como elevados, se comparados com a renda média brasileira (US\$ 7770,00 anuais ou US\$ 647,5 mensais, de acordo com o Programa das Nações Unidas para o Desenvolvimento - PNUD) (PNUD, 2004). Este rendimento equivale a R\$ 1554,0, ou 6,0 salários mínimos, considerando o valor do salário mínimo ( R\$ 260,00), vigente na época da coleta de dados.

Os dados relativos aos dos alunos mostram que há um predomínio de famílias (53,8\%) com rendimentos que variam entre 2,1 a 6 salários mínimos, valores que podem ser considerados similares com a renda média da população brasileira.

Quando questionados sobre a adoção de mudança de hábitos alimentares nos últimos dois anos, foi possível verificar que a maioria $\mathbf{5 4 , 8 \% )}$ dos professores não 
incorporou nenhuma alteração, enquanto que a maioria dos alunos, 69,3\%, registra que passou por mudanças na alimentação durante o período considerado.

Foi solicitado aos entrevistados que informassem sobre a adoção de hábito alimentar não tradicional/diferenciado. Os resultados mostraram que a maioria dos professores e alunos, $83,3 \%$ e $77,9 \%$, respectivamente, relatou que não adota essa modalidade de prática alimentar.

Ainda foi possível identificar que durante a compra dos alimentos, alguns atributos são considerados pelos integrantes da pesquisa, conforme mostrado na Tabela 4.

Tabela 4. Atributos dos alimentos, considerados durante o processo de compra, citados por professores e alunos. São Paulo, 2004

\begin{tabular}{|c|c|c|c|c|}
\hline \multirow{3}{*}{ Atributos } & \multicolumn{4}{|c|}{ Citações } \\
\hline & \multicolumn{2}{|c|}{ Professores } & \multicolumn{2}{|c|}{ Alunos } \\
\hline & $\mathrm{n}^{\mathrm{o}}$ & $\%$ & $\mathrm{n}^{\mathrm{o}}$ & $\%$ \\
\hline $\begin{array}{l}\text { Informações que assegurem a qualidade } \\
\text { do alimento (maior durabilidade, maior } \\
\text { conteúdo de nutrientes) }\end{array}$ & 38 & 26,20 & 212 & 25,82 \\
\hline Preço & 33 & 22,75 & 205 & 24,96 \\
\hline Aparência & 29 & 20,00 & 185 & 22,53 \\
\hline Sabor/aroma & 19 & 13,10 & 127 & 15,47 \\
\hline $\begin{array}{l}\text { Garantia de informações de que não há } \\
\text { resíduos }\end{array}$ & 15 & 10,35 & 67 & 8,16 \\
\hline Outra & 11 & 7,58 & 25 & 3,05 \\
\hline TOTAL & 145 & 100,00 & 821 & 100,00 \\
\hline
\end{tabular}

Nota: respostas múltiplas dos professores para a questão, totalizando 145. Respostas múltiplas dos alunos para a questão, totalizando 821.

Examinando a tabela 4, é possível observar que, para este grupo de consumidores, (professores e alunos da área de nutrição) a maior preocupação no momento da compra está relacionada com a qualidade do produto, superando até mesmo a proporção de citações relacionadas aos preços dos alimentos. 


\subsection{Conhecimento e opinião dos entrevistados no tocante a transgenia}

Cabe lembrar que o instrumento adotado para a obtenção dos dados envolveu uma seção que reuniu as questões visando conhecer o entendimento dos professores e alunos em relação aos organismos/alimentos transgênicos. Os entrevistados foram questionados sobre o entendimento que detinham para conceituar os produtos ou alimentos transgênicos. As respostas foram registradas na Tabela 5, apresentada a seguir

Tabela 5. Distribuição percentual das citações dos professores e alunos de acordo com o conceito relativo aos produtos/alimentos transgênicos.São Paulo, 2004

Conceitos citados

Entrevistados/ Percentual de citações

“modificados,alterados geneticamente, que sofreram mutação

Professores 47,6

Alunos genética; alimentos provenientes de plantas ou animais modificados geneticamente; alimentos que sofreram alguma alteração em sua genética/ é quando muda o genoma (sic)”.

“alimentos modificados geneticamente para ter características

melhores (aumentar a durabilidade, resistir a pragas, ter ganho nutricional, aumentar a produtividade.)”

"alimentos transgênicos são alimentos geneticamente modificados, mas com genes de espécies diferentes/ alimentos que receberam DNA de outra espécie: ex: bactérias, insetos para vegetais"

“alimentos modificados por ação humana, alimentos modificados em laboratório; alimentos diferentes do que a natureza produz, alimentos que passam por modificações não naturais/ alimentos que têm um processo de formação diferente do normal em relação à genética”

"Alimento modificado; alimento que tem sua semente modificada”

“Alimentos melhorados geneticamente”

"Resistentes a pragas na lavoura”

$0,0 \quad 0,4$

Não respondeu corretamente/ não respondeu 
Observa-se que cerca da metade (47,6\%) dos professores, e a maioria dos alunos, (65\%), registrou conceitos que podem ser considerados corretos, de acordo com a literatura especializada sobre o assunto, embora fossem citadas definições sem detalhamento, como por exemplo "é quando muda o genoma”. A definição mais próxima do correto foi fornecida por reduzida proporção dos entrevistados, 2,4\% dos professores e $0,7 \%$ dos alunos, a saber: "alimentos geneticamente modificados, mas com genes de espécies diferentes; alimentos que receberam DNA de outra espécie: exemplo: bactérias, insetos para vegetais”. Esta seria a resposta mais apropriada, que faz referência a inserção de genes de espécies diferentes. Substancial parcela 40,5\%, dos professores, e $12,6 \%$ dos alunos complementaram suas respostas citando que a modificação genética ocorre para melhorar as características dos produtos. Citações fornecidas por 2,4\% dos professores e $8,3 \%$ dos alunos revelam que os mesmos não compreendem a definição de transgênicos. Estes afirmam que os produtos/ alimentos transgênicos são produzidos em laboratórios, que são modificados por ação humana, afirmativas que podem ser classificadas como corretas, porém os entrevistados não conseguem explicar de que maneira é implementada esta modificação.

Respostas errôneas foram fornecidas por 4,8\% dos professores, como: "Procuro ler em revistas especializadas, acompanho documentários e pesquisas”; “alimentos formados a partir de dois gêneros de diferentes espécies, com cruzamento genético (gens vegetal com gens animal) (sic)”. Respostas consideradas erradas também foram fornecidas por 6,1\% dos alunos, tais como: “modernidade, alimentos mais garantidos”; “alimentos que sofreram adulteração por química”; "produtos alterados em sua forma, essência, sabor, etc.”; “alimentos modificados geneticamente, ou seja, são injetados produtos químicos”; “alimentos que muitas vezes são maléficos à nossa saúde, porque pode desenvolver células cancerígenas (sic)”.

A falta de clareza e detalhamento nas respostas pode estar relacionada com o fato do tema estar constantemente sendo relacionado com polêmicas, explorado de maneira “apaixonada” pela mídia, de forma a limitar que conceitos corretos e de fácil interpretação sejam raramente apresentados à população. Oda \& Soares, em 2000, em 
pesquisa realizada tendo por base amostra de 550 brasileiros moradores de diversas capitais, constataram que $47 \%$ dos entrevistados nunca tinham ouvido falar em biotecnologia. Provavelmente, em 2004, ano da realização da coleta de dados da presente pesquisa, percentual similar ao identificado pelos referidos autores, da população continue não tendo acesso a informações corretas sobre o tema.

Ao serem questionados sobre a prática de acompanhar as notícias veiculadas pelos meios de comunicação referentes aos alimentos transgênicos, os entrevistados forneceram as seguintes respostas que foram reunidas na Tabela 6, mostrada a seguir. 
Tabela 6. Tipos de notícias veiculadas pela mídia sobre transgênicos, citadas por professores e alunos. São Paulo,2004

\begin{tabular}{l} 
Notícias citadas \\
\hline “Estão ocorrendo debates, polêmicas; a polêmica é grande, \\
pois não existe uma confirmação científica que comprove \\
a seguridade dos transgênicos; faz-se muito 'terrorismo' \\
dos alimentos transgênicos”
\end{tabular}

"Não há informações seguras; os alimentos transgênicos devem conter informações nos rótulos; não se pensa em saúde”

"Sabe-se que as pessoas estão desinformadas; a população não sabe a diferença entre ogm e transgênico;o acesso da população às revistas científicas é quase nulo, ficando somente para os pesquisadores”

"Verificam-se informações favoráveis (mais qualidade, maior vida útil); não ficou provado nenhum malefício à saúde”

"Os transgênicos ainda não foram liberados pelo governo; o Paraná não aceita a soja transgênica; o governo deve regulamentar as atividades envolvendo transgênicos”

"Não é uma tecnologia boa; alimentos transgênicos é (sic) um problema politicamente empresarial; vê controvérsias que ressaltam o valor negativo e não veiculam os valores positivos; na medicina o uso de transgênicos pode veicular alguma doença (câncer)”

"Verifica-se que a população resiste, tem dúvidas"

"Há notícias sobre o plantio e pesquisas no Brasil; já verificou informações sobre a soja, legalização da soja"

Outros

O entrevistado não tem acompanhado as notícias, não soube responder

$\begin{array}{llll}2 & 4,1 & 6 & 2,0\end{array}$

$8 \quad 16,4 \quad 22 \quad 7,1$

$2 \quad 4,1 \quad 10 \quad 3,3$

Não respondeu 
Nota: respostas múltiplas dos professores para a questão, totalizando 49 citações. Respostas múltiplas dos alunos para a questão, totalizando 308 citações.

Analisando-se os dados da tabela 6, observa-se que 16,7\% dos professores e 30,5\% dos alunos não souberam responder, ou não as têm acompanhado as notícias veiculadas referentes a alimentos transgênicos. O reconhecimento da existência de polêmica causada pelos transgênicos foi citada por 35,7\% dos professores 23,3\% dos alunos enquanto que a preocupação com a segurança dos transgênicos foi informada por 28,6\% e 12,01\%, respectivamente. Observa-se que as notícias mais mencionadas relacionam-se com a insegurança e polêmica com que o tema foi veiculado constantemente pela mídia, especialmente nos períodos que antecederam a votação da nova legislação brasileira sobre o assunto.

Foi solicitado aos entrevistados que se manifestassem sobre a crença na possibilidade de o Brasil elaborar uma legislação referente à biotecnologia. Os dados obtidos foram reunidos na tabela 7 . 
Tabela 7. Citações dos professores e alunos no tocante à crença de que o Brasil poderá elaborar legislação especifica à biotecnologia. São Paulo, 2004

\begin{tabular}{|c|c|c|c|c|}
\hline \multirow[t]{3}{*}{ Citações } & \multicolumn{4}{|c|}{ Citações } \\
\hline & \multicolumn{2}{|c|}{ Professores } & \multicolumn{2}{|c|}{ Alunos } \\
\hline & $\mathrm{n}^{\mathrm{c}}$ & $\%$ & $\mathrm{n}^{\mathrm{o}}$ & $\%$ \\
\hline $\begin{array}{l}\text { Regulamentação das atividades envolvendo } \\
\text { transgênicos:plantio, pesquisa, comércio. "Sim, deve-se } \\
\text { regulamentar a pesquisa e a comercialização de produtos } \\
\text { transgênicos; garantir a segurança dos consumidores, } \\
\text { pesquisadores e pessoas envolvidas; as pesquisas devem } \\
\text { ser apoiadas, subsidiadas" }\end{array}$ & 14 & 29,8 & 78 & 28,2 \\
\hline $\begin{array}{l}\text { Informação/educação: “A legislação deve ajudar a } \\
\text { população, com informações, deve haver rotulagem. Deve } \\
\text { haver educação nutricional” }\end{array}$ & 10 & 21,3 & 26 & 9,4 \\
\hline Responderam apenas “não”. & 9 & 19,2 & 59 & 21,3 \\
\hline $\begin{array}{l}\text { Vigilância das atividades envolvendo transgênicos: "Sim, } \\
\text { poder-se-ia criar meio de inspeções industriais e nos } \\
\text { lugares de acesso dos consumidores" }\end{array}$ & 3 & 6,3 & 9 & 3,3 \\
\hline $\begin{array}{l}\text { Segurança dos transgênicos: "Sim, deve-se permitir a } \\
\text { divulgação e a venda quando for comprovada a } \\
\text { segurança, em termos de saúde e de meio ambiente, dos } \\
\text { transgênicos" }\end{array}$ & 2 & 4,3 & 7 & 2,5 \\
\hline $\begin{array}{l}\text { Não compreendeu a questão: “Não, pois o país é atrasado } \\
\text { em relação a tecnologias. O país não cumpre as leis”. }\end{array}$ & 2 & 4,3 & 5 & 1,8 \\
\hline $\begin{array}{l}\text { Outros (com alimentos o controle deve ser mais rigoroso; } \\
\text { deve-se defender o meio ambiente; vão liberar por } \\
\text { motivos políticos e econômicos) }\end{array}$ & 0 & 0,0 & 7 & 2,4 \\
\hline Não sabe & 5 & 10,6 & 3 & 1,1 \\
\hline Não respondeu & 2 & 4,2 & 83 & 30,0 \\
\hline TOTAL & 47 & 100,0 & 277 & 100,0 \\
\hline
\end{tabular}

Nota: respostas múltiplas dos professores para a questão, totalizando 47 citações. Respostas múltiplas dos alunos para a questão,totalizando 277 citações. 
Sobre legislação envolvendo a biotecnologia, é sugerido por 29,8\% dos professores e 28,2\% dos alunos que as atividades que envolvam transgênicos como por exemplo, pesquisa, plantio e comercialização sejam regulamentadas. Sugestões para que a população tenha meios de manter-se informada sobre questões relacionadas a segurança alimentar, como educação nutricional e rotulagem foram fornecidas por $21,3 \%$ dos professores e por 9,4\% dos alunos entrevistados. Cabe ressaltar que a rotulagem de alimentos transgênicos é obrigatória no Brasil desde 2003, conforme descrito pormenorizadamente na seção 2.5.3 Normas de Rotulagem.

No tocante aos benefícios/malefícios que os transgênicos possam causar para o homem, , foi solicitado aos professores que registrassem suas opiniões. Tendo por base os dados informados, $14,3 \%$ dos professores e $9,6 \%$ dos alunos acreditam que os transgênicos sejam benéficos à saúde; 4,8\% e 20,2\%, respectivamente, crêem que os transgênicos causam danos à saúde; 11,9\% dos professores e 26,2\% dos alunos são indiferentes; 7,1\% dos docentes e 13,1\% dos alunos não têm opinião e 62,2\%dos professores e $28,5 \%$ dos alunos registraram outras respostas. Integram o bloco identificado como “outras respostas" as citações destes 62,2\% de professores e 28,5\% dos alunos, relacionadas à falta de pesquisas na área para que seja possível uma posição conclusiva sobre os possíveis benefícios/malefícios que transgênicos possam causam ao ser humano. Alguns entrevistados que citaram informações classificadas como "outras citações” (15,4\% e 10,12\%) informaram ambiguamente que a transgenia pode trazer tanto benefícios quanto malefícios.

Observa-se que a maioria dos professores, 62,2\% não responde diretamente se os transgênicos são benéficos ou maléficos. Estes entrevistados, de maneira geral, têm dúvidas sobre a seguridade de um alimento transgênico, o que pode ser observado ao examinar as citações do tipo: “Ainda faltam, pesquisas para se ter uma conclusão. Não se sabe como será, ao longo dos anos...”

Foi solicitado aos entrevistados que citassem algum produto transgênico que não fosse alimento. Os resultados revelaram que 50\% dos professores e $31 \%$ dos alunos responderam desconhecer a existência, e ainda, 16,7\% e 45,5\%, respectivamente, deixaram de responder a questão. Plantas não comestíveis, como eucalipto e orquídea, 
foram citadas por 9,5\% dos professores e 10,1\% dos alunos e algodão, por 7,1\% e 2,9\%, respectivamente, como sendo os produtos conhecidos. Dos entrevistados, 11,5\% dos professores e 2,5\% dos alunos lembraram dos medicamentos. 2,4\% dos professores citaram bactérias e estas não foram referidas pelos alunos. Herbicida e fertilizantes foram mencionados por $2,4 \%$ dos professores e por $0,4 \%$ dos alunos. Animais, clones e cosméticos não foram mencionados pelos professores, mas o foram por 4,3\%; 0,7\% e 0,4\% dos alunos. Ainda tendo por base a questão sobre o conhecimento relativo a outros produtos transgênicos, que não os alimentos, como leite e óleo de soja, “miojo®”, batatas importadas, foram citados por $1,4 \%$ dos alunos entrevistados, sem serem apontados pelos professores.

Observa-se que metade dos professores e 31\% dos alunos não conhecem outro produto transgênico a não ser alimento. Merecem destaque as proporções de $16,7 \%$ e 45,5\% dos professores e alunos, respectivamente, que não responderam à questão.

Foi possível observar que 52,4\% dos professores e 37,5\% dos alunos acreditam na necessidade de se disponibilizar os alimentos transgênicos para a população do Brasil; 42,9\% e 41,2\%, respectivamente, rejeitam esta idéia e 4,8\% dos professores e 19,1\% dos alunos não emitiram a opinião sobre esta questão.

Os entrevistados foram questionados se acreditam que o emprego das sementes transgênicas possa alterar os preços dos grãos e, conseqüentemente, os preços dos alimentos comercializados no país. As respostas obtidas junto aos entrevistados podem ser observadas na tabela, mostrada a seguir. 
Tabela 8. Citações dos professores e alunos relativas à crença que o uso de sementes transgênicas poderá alterar os preços dos alimentos. São Paulo, 2004

\begin{tabular}{lll}
\hline Citações & Percentagem & \\
\hline Sim (sem justificativa). & Professores & Alunos
\end{tabular}

“Sim, os gastos com plantação e colheita são menores” (idéia $54,7 \quad 41,1$ de que os alimentos ficarão mais baratos).

“Sim, vai aumentar” (sem justificativa).

$16,6 \quad 15,5$

“Sim, pode aumentar no início e diminuir o preço depois; $4,8 \quad 1,4$ $2,4 \quad 1,4$ quando tivermos domínio seguro da tecnologia, talvez a queda do preço da semente”.

Sim, vai alterar por que: "são dispostos recursos, tecnologia e mão de obra qualificada; envolve mais pesquisas, a qualidade $0,0 \quad 20,1$ do alimento vai melhorar, vai haver monopólio das sementes; os produtores terão sempre que comprar as matrizes, que são importadas; o transgênico é novidade e com isso o preço dos grãos subiria; as sementes transgênicas irão acrescentar algum nutriente e com certeza isso será cobrado”

Sim, vai diminuir. $0,0 \quad 4,6$

Depende das políticas econômicas; vai depender do monopólio $4,8 \quad 1,4$ e de interesses particulares.

Não

$16,7 \quad 9,4$

Não tem opinião

$0,0 \quad 0,4$

Não respondeu

$0,0 \quad 4,7$

TOTAL $100,0 \quad 100,0$ 
A análise das respostas permite verificar que mais da metade dos professores $(54,7 \%)$ e expressiva parcela dos alunos (41,1\%) apenas responderam afirmativamente (sim), sem registro de justificativas e $16,7 \%$ e $9,4 \%$, respectivamente, responderam apenas "não", sem justificar a resposta, o que possivelmente revela falta de embasamento para a discussão do tema. A idéia de que os alimentos serão comercializados com preços menores foi fornecida por $16,7 \%$ dos professores e 15,5\% dos alunos e as justificativas fornecidas são consideradas coerentes, especialmente quando se considera as opiniões emitidas freqüentemente por agricultores e parcela de cientistas. Respostas registradas por 20,1\% dos alunos indicam que estes acreditam que o preço vai aumentar. Infere-se que estes acreditam na premissa de que tecnologia envolve custos, porém sem trazer retorno, ou seja, se preocupam somente com os custos da nova tecnologia, esquecendo-se de analisar se a implantação da transgenia poderá reduzir o valor de plantio, manutenção, colheita.

Questionados se acreditam que a disponibilidade de alimentos transgênicos possa controlar a "fome que atinge parte da população mundial", professores e alunos registraram as citações que podem ser observadas na Tabela 9, mostrada a seguir. 
Tabela 9. Citações dos professores e alunos relativas a crença que os alimentos transgênicos poderão contribuir para diminuir o contingente de indivíduos expostos à fome ,em distintos paises.São Paulo, 2004

\begin{tabular}{|c|c|c|}
\hline Citações & \multicolumn{2}{|c|}{ Percentagem } \\
\hline & Professores & Alunos \\
\hline Sim & 35,7 & 19,5 \\
\hline Sim, pois a produção seria maior & 7,1 & 5,0 \\
\hline $\begin{array}{l}\text { Sim, apesar de ser contra transgênicos, acredita que pode } \\
\text { controlar a fome }\end{array}$ & 2,4 & 1,1 \\
\hline Não, não pode controlar a fome no mundo & 23,8 & 34,7 \\
\hline $\begin{array}{l}\text { "Não, não existe falta de alimentos e sim má distribuição de } \\
\text { renda, desperdício” }\end{array}$ & 14,3 & 5,8 \\
\hline $\begin{array}{l}\text { "Não, pois a fome é algo complexo que envolve diversos } \\
\text { fatores" }\end{array}$ & 9,5 & 16,2 \\
\hline $\begin{array}{l}\text { "Não, pois a fome é um problema de } \\
\text { política/administração/economia" }\end{array}$ & 7,1 & 7,9 \\
\hline $\begin{array}{l}\text { "Não, pois se os transgênicos trouxerem danos à saúde, a } \\
\text { população sofrerá as conseqüências" }\end{array}$ & 0,0 & 4,0 \\
\hline Outros & 0,0 & 1,5 \\
\hline Não respondeu & 0,0 & 0,7 \\
\hline Não sabe & 0,0 & 3,6 \\
\hline TOTAL & 100,0 & 100,0 \\
\hline
\end{tabular}

Tendo por base os dados da tabela 9, observa-se a maioria dos entrevistados, (54,8\% dos professores e 68,6\% dos alunos) não acredita que a disponibilidade de alimentos transgênicos possa diminuir a fome no mundo.

Em relação a pesquisas envolvendo transgênicos, os entrevistados foram questionados se concordam com o aumento de recursos destinados a pesquisas 
científicas que priorizam as análises tendo como foco os transgênicos. Os resultados foram resumidos na Tabela 10.

Tabela 10. Citações dos professores e alunos de acordo com o apoio para a ampliação de recursos destinados a pesquisas que priorizem os alimentos transgênicos. São Paulo, 2004

Citação Percentagem

Professores

Alunos

Sim $64,3 \quad 38,6$

"Sim, porque desta forma haverá mais embasamento, provas científicas para se aceitar ou não os transgênicos”

$11,9 \quad 25,6$

“Sim, pesquisas sempre devem ser apoiadas.” $11,9 \quad 12,6$

Não $7,1 \quad 7,6$

"Não, porque há pesquisas mais importantes para serem feitas; podem usar estes recursos para outros fins; deve ser $4,8 \quad 7,2$ feita pesquisa em outras áreas, como educação; devem pesquisar a cura de doenças como o câncer, a aids; estes recursos poderiam ser destinados para acabar com a fome”

Não respondeu

TOTAL $100,0 \quad 100,0$

Observa-se que $88,1 \%$ dos professores e 76,8\% dos alunos são favoráveis a pesquisa envolvendo transgênicos.

No tocante à legislação de alimentos transgênicos, foi incluída, na pesquisa, questão que possibilitasse identificar a "posição"/opinião dos entrevistados no que diz respeito à rotulagem obrigatória. Praticamente a totalidade dos entrevistados (95,2\% dos professores e 94,9\% dos alunos) é favorável à rotulagem. Sobre uma legislação específica para rotulagem, foi solicitado, apenas aos professores, que se manifestassem quanto à crença se a legislação será ou não cumprida. Mais da metade destes (52,4\%), acredita que a legislação não será cumprida; 35,7\% acreditam a legislação específica 
sobre rotulagem será respeitada e 11,9\% não souberam responder. Ressalta-se que no Brasil já existe uma legislação referente a rotulagem obrigatória de alimentos transgênicos ou que contenham mais de 1\% de ingredientes transgênicos desde 2003. (Decreto $\left.n^{0} 4680 / 2003\right)$.

Foi solicitado, ainda, para que os professores registrassem algumas penalidades que acreditassem, deveriam ser aplicadas aos que descumprirem a legislação. Os dados obtidos junto aos entrevistados possibilitaram a elaboração da Tabela 11, mostrada a seguir.

Tabela 11. Citações dos professores relativas à penalidade que acreditam deveriam ser impostas para os agentes que não cumprirem a legislação relativa à rotulagem. São Paulo, 2004

\begin{tabular}{lr}
\hline Citação & Percentagem \\
\hline Multa & 21,4 \\
$\begin{array}{l}\text { “Cassação do alvará de funcionamento, fechamento } \\
\text { estabelecimento, encerrar a produção do produto” }\end{array}$ & 21,4 \\
$\begin{array}{l}\text { “As penalidades já estão previstas pela legislação” } \\
\text { Respondeu fornecendo mais de uma alternativa, como por exemplo - } \\
\text { "retirar o produto do mercado e multar” }\end{array}$ & 19,0 \\
“Prisão” & 11,9 \\
“Retirar o produto do mercado” & 4,8 \\
“Deve ser rigorosa” & 4,8 \\
“Existe pena para grandes empresários?” & 2,4 \\
Não respondeu & 2,4 \\
TOTAL & 11,9 \\
\hline
\end{tabular}

A responsabilidade de fiscalização para o cumprimento da legislação relativa à rotulagem foi incluída no rol das perguntas que integram o questionário específico 
adotado para a coleta de dados junto aos professores. Segundo estes, a responsabilidade deveria ser assumida pelas seguintes instituições/entidades: ministérios (saúde, agricultura, justiça): 31\%; órgãos de defesa do consumidor: 16,7\%. A Agência Nacional de Vigilância Sanitária (Anvisa), que é vinculada ao ministério da saúde, foi citada por 16,7\%. A Polícia Federal foi citada por 2,4\% dos entrevistados e o Serviço de Inspeção Federal (SIF) também foi mencionado por 2,4\%. Foram observadas ainda, respostas superficiais, como “qualquer órgão composto por pessoas sérias” citada por 2,4\% dos entrevistados e “todos os órgãos envolvidos” , citada por 2,4\%. Pequena parcela (2,4\%) dos entrevistados, manifestou-se demonstrando desconhecimento, ao propor a "criação de um FDA”. Para 2,4\% dos entrevistados, a responsabilidade cabe a duas entidades, Ministério da Agricultura e Anvisa. Parcela expressiva dos entrevistados, (21,2\%) não soube responder a quem caberia a responsabilidade de fiscalização sobre o cumprimento da legislação relativa à rotulagem.

Em relação à possibilidade de melhora da perfomance da economia brasileira pela liberação para a produção e comercialização de transgênicos, os professores registraram as citações que são mostradas na Tabela 12.

Tabela 12. Citações dos professores relativas à crença que a economia brasileira poderá se beneficiar em decorrência da produção e comercialização de transgênicos.São Paulo, 2004

\begin{tabular}{lr}
\hline Citação & Percentagem \\
\hline “Não” & 35,7 \\
“Sim, devido a maior produção de alimentos.” & 33,3 \\
“Sim, devido ao aumento na exportação brasileira.” & 4,8 \\
NSim” & 4,8 \\
TOTAL & 21,4 \\
\hline
\end{tabular}


Indagados sobre a crença com relação à possibilidade de a população brasileira estar consumindo alimentos transgênicos sem prévio conhecimento, a ampla maioria (81\%) dos professores e alunos (61,7\%) respondeu afirmativamente e 2,4\% dos professores e 3,6\% dos alunos responderam negativamente. Para 4,8\% e 0,7\%, respectivamente, dos entrevistados, a população consome alimentos transgênicos sem conhecimento, citando que, na maioria das situações, estes alimentos são importados. Identificou-se ainda que $7,1 \%$ dos professores e $4,3 \%$ dos alunos, acredita que ocorra consumo de alimentos transgênicos, e cita exemplos, como leite de soja, derivados de soja, sucos em pós, achocolatados, cereais matinais. Na opinião de 2,4\% e 10,5\% dos entrevistados, os brasileiros consomem produtos transgênicos sem conhecimento em decorrência do fato de não terem o hábito da leitura dos rótulos dos produtos e para 2,4\% dos professores, o consumo de transgênicos sem o prévio conhecimento da população ocorre, porque não há o cumprimento da legislação vigente. Para 1,4\% dos alunos, os brasileiros consomem produtos transgênicos sem saber porque não há fiscalização. Ainda de acordo com os alunos, (14,4\%), a população brasileira consome alimentos transgênicos sem saber porque a informação não está evidente nos rótulos.

Os brasileiros realmente consomem produtos transgênicos ou que contenham ingredientes transgênicos devido ao fato das empresas não estarem cumprindo o que registra o Decreto 4680/2003, que determina a rotulagem de alimentos transgênicos e de alimentos com mais de 1\% de ingredientes transgênicos. Esse foi um motivo citado ela minoria (2,4\% dos professores). Vale mencionar que este motivo não foi mencionado pelos alunos. O consumo de transgênicos sem o conhecimento da população também pode ocorrer pela falta de fiscalização dos órgãos competentes, motivo mencionado por apenas $1,4 \%$ dos alunos, sendo importante ressaltar que nenhum professor mencionou este motivo. O fato de consumir transgênicos sem conhecimento não se deve a falta de leitura dos rótulos, como citaram alguns entrevistados, assim como também não decorre do fato da informação não estar evidente no rótulo, como também afirmaram 14,4\% dos alunos. 
Os entrevistados foram questionados se estariam dispostos a pagar a mais pelos alimentos, se fosse assegurado que não eram transgênicos. Os resultados obtidos foram reunidos na tabela 13:

Tabela 13. Disposição dos professores e alunos de pagar valores adicionais por produtos comprovadamente não-transgênicos. São Paulo, 2004

\begin{tabular}{lrr}
\hline Disposição de pagar valores adicionais & \multicolumn{2}{c}{ Percentual } \\
\hline Não estão dispostos & professores & alunos \\
$10 \%$ & 2,4 & 67,1 \\
$30 \%$ & 2,4 & 4,7 \\
$50 \%$ & 11,9 & 10,5 \\
$75 \%$ & 2,4 & 1,8 \\
$100 \%$ & 4,8 & 4,0 \\
Não respondeu & & 5,0 \\
TOTAL & 100,0 & 100,0 \\
\hline
\end{tabular}

Observa-se que substancial maioria dos professores (76,2\%) e dos alunos $(67,1 \%)$ não está disposta a pagar valores adicionais para ter a certeza de que o produto adquirido não é transgênico. Os dados da tabela 4 indicam que a maioria dos entrevistados revelou preocupação com a qualidade do produto, item que superou as citações relativas ao preço e, comparando-se os resultados mostrados nas duas tabelas, pode-se afirmar que a certificação de isenção de transgenia não é um fator considerado de qualidade.

Questionados se a utilização de sementes transgênicas poderia causar algum impacto ao meio ambiente, os professores e alunos forneceram as respostas apresentadas na tabela 14. 
Tabela 14. Citações dos professores e alunos relativas aos possíveis impactos ao meio ambiente, decorrentes do uso de sementes transgênicas. São Paulo, 2004

Citação
Sim
"Sim, pois ainda não existem estudos que provam que as
sementes transgênicas não afetam o meio ambiente; existem
estudos que comprovam que o meio ambiente é afetado".

\section{Percentagem}

Professores

Alunos

7,1

5,4

19,0

0,7

estudos que comprovam que o meio ambiente é afetado”.

"Sim, porque as sementes são manipuladas no laboratório e não se sabe o que se faz com ela; faltam informações, pesquisas; estas sementes não fazem parte da natureza”.

"Sim, porque altera o ciclo natural do meio; pode alterar a cadeia alimentar; as sementes perdem sua verdadeira origem; pode haver o risco de mutação com sementes normais; tudo tem que acontecer naturalmente”.

"Sim, afeta o meio ambiente, porque se há mudança no alimento, pode haver mudança no solo ou meio ambiente".

"Sim, porque as sementes poderiam não ser reutilizadas"

"Não, porque se usa menos agrotóxico; as sementes

Não respondeu

Outros

Examinando os dados, verifica-se que 52,3\% dos professores e 40,0\% dos alunos acreditam que o uso de sementes transgênicas afeta o meio ambiente, por motivos 
diversos. Observa-se que 19\% dos professores e 43\% dos alunos não souberam comentar sobre a questão.

No que se refere ao emprego de alimentos transgênicos, como soja e milho na ração para animais, freqüentemente criados para o consumo humano, obtiveram-se os registros (tabela 15) mostrados a seguir:

Tabela 15. Posição de professores e alunos com relação ao uso de alimentos transgênicos, como soja e milho, na ração para animais. São Paulo, 2004

\begin{tabular}{|c|c|c|}
\hline & \multicolumn{2}{|c|}{ Percentagem } \\
\hline Posição (concorda ou não concorda) & Professores & Alunos \\
\hline $\begin{array}{l}\text { “Não concorda, pois o que não é permitido para os homens, não } \\
\text { deve ser permitido para os animais”. }\end{array}$ & 26,2 & 21,6 \\
\hline $\begin{array}{l}\text { "Não concorda, porque, dependendo do animal, será alimento } \\
\text { do homem, como carne e leite”. }\end{array}$ & 19,0 & 13,0 \\
\hline “Sim” (sem argumentar). & 14,3 & 6,1 \\
\hline $\begin{array}{l}\text { “Sim, pois o custo da ração pode ser mais baixo; a qualidade da } \\
\text { carne do animal pode ser melhorada com o emprego de } \\
\text { transgênicos na ração". }\end{array}$ & 7,1 & 9,0 \\
\hline $\begin{array}{l}\text { "Sim, pois se os transgênicos são bons para o homem, podem } \\
\text { ser bons para os animais" }\end{array}$ & 7,1 & 4,0 \\
\hline $\begin{array}{l}\text { "Sim, pois o emprego de transgênicos na ração poderia ajudar } \\
\text { nas pesquisas". }\end{array}$ & 4,8 & 4,3 \\
\hline $\begin{array}{l}\text { "Sim, o emprego de transgênicos na ração não deve afetar a } \\
\text { saúde dos animais" }\end{array}$ & 2,4 & 1,4 \\
\hline “Não, porque não há necessidade” & 0,0 & 2,5 \\
\hline “Não, pois pode alterar os hábitos alimentares dos animais”. & 0,0 & 1,4 \\
\hline Não têm opinião & $\begin{array}{r}0,0 \\
19,0\end{array}$ & $\begin{array}{r}35,4 \\
1,4\end{array}$ \\
\hline $\begin{array}{l}\text { Não respondeu } \\
\text { TOTAL }\end{array}$ & 100,0 & 100,0 \\
\hline
\end{tabular}


Na presente pesquisa os entrevistados foram questionados sobre a crença relativa a “superioridade” dos alimentos orgânicos (do ponto de vista qualitativo) em relação aos alimentos transgênicos.

Os referidos tipos de alimentos foram comparados porque ambos provocam questionamentos e polêmica, uma vez que para obtenção dos dois tipos são necessários meios distintos dos tradicionalmente adotados para a obtenção de alimentos. Objetivouse verificar se a crença de que os orgânicos, cujas sementes não são modificadas, seriam considerados superiores aos transgênicos. 
Tabela 16. Citações dos professores e alunos relativas à crença sobre a superioridade dos alimentos orgânicos comparativamente aos transgênicos. São Paulo,2004

Citações

"Sim, porque são naturais não têm agrotóxicos,

\begin{tabular}{lll} 
Professores & \multicolumn{2}{l}{ Alunos } \\
n. $\%$ & n. $\%$
\end{tabular}
pesticidas. A natureza fez os orgânicos do jeito que $14 \quad 32,6 \quad 98 \quad 32,6$ eles são.”

"Sim, porque não houve modificação genética. As $5 \quad 11,6 \quad 41 \quad 13,6$ características originais do alimento são mantidas."

"Sim, porque os orgânicos são mais saudáveis.” $1 \quad 2,3 \quad 23 \quad 7,6$

Sim. $2 \quad 4,6 \quad 14 \quad 4,6$

"Não, porque os alimentos orgânicos são deficitários em alguns nutrientes."

$2 \quad 4,6 \quad 14 \quad 4,6$

Não (não argumenta) $0 \quad 0,0 \quad 10 \quad 3,3$

“Cada um tem suas particularidades, são diferentes, $\begin{array}{lllll}4 & 9,3 & 3 & 1,0\end{array}$ não dá para comparar.”

$\begin{array}{llllll} & \text { "Uma planta pode ser orgânica e transgênica. A } & 3 & 7,0 & 3 & 1,0\end{array}$ qualidade pode ser a mesma."

Sem opinião.

$10 \quad 23,3 \quad 83 \quad 27,7$

Não respondeu.

$2 \quad 4,6 \quad 8 \quad 2,7$

Outros

$\begin{array}{llll}0 & 0 & 4 & 1,3\end{array}$

TOTAL

$43 \quad 100,0 \quad 301 \quad 100,0$

Nota: respostas múltiplas dos professores para a questão, totalizando 43 citações. Respostas múltiplas dos alunos para a questão, totalizando 301 citações.

A maioria dos entrevistados (51,1\% dos professores e 58,4\% dos alunos) acredita na superioridade dos alimentos orgânicos quando comparados aos transgênicos. Cerca de um terço dos entrevistados (32,6\% dos professores e 32,6\% dos alunos) forneceu argumentos relacionados à principal característica de um produto orgânico - "isenção do 
uso de adubos e defensivos químicos sintéticos” (Penteado, 2000)- para acreditar que os orgânicos sejam melhores que os transgênicos. Parcela reduzida dos entrevistados, 11,6\% dos professores e 13,6\% dos alunos citou que o fato do produto orgânico não ter alteração genética, característica intrínseca aos transgênicos, indica que ele seja superior. O raciocínio de que os dois tipos de alimentos são distintos, não sendo possível compará-los, expresso por 9,3\% dos professores e 1,0\% dos alunos tem fundamento, visto que estes alimentos são obtidos por meio de diferentes métodos. Cabe lembrar que um produto pode ser classificado transgênico e orgânico, ou seja, uma semente pode ser geneticamente modificada e ser cultivada, respeitando-se as recomendações preconizadas pela agricultura orgânica, o que foi mencionado por apenas 7,0\% dos professores e $1,0 \%$ dos alunos.

Notem-se também as expressivas parcelas de professores (23,3\%) e alunos $(27,7 \%)$ que declaram não ter opinião sobre o assunto.

Os entrevistados, caso acreditassem na superioridade da qualidade dos alimentos orgânicos, também foram questionados sobre a fonte de informações adotada para reconhecer a vantagem (relativa)

Tabela 17. Distribuição das citações dos professores e alunos, de acordo com as fontes consultadas para a conceituação de que alimentos orgânicos sejam superiores aos transgênicos. São Paulo,2004

\begin{tabular}{lrrrr}
\hline Citações & Professores & Alunos \\
\hline & $\mathrm{n}$. & $\%$ & $\mathrm{n}$. & $\%$ \\
informação de revistas & 15 & 25,9 & 91 & 20,0 \\
informação de jornais & 7 & 12,1 & 52 & 11,4 \\
Internet & 7 & 12,1 & 46 & 10,1 \\
livros & 6 & 10,3 & 45 & 10,0 \\
Artigos científicos & 6 & 10,3 & 0 & 0,0 \\
informação de programa de televisão & 6 & 10,2 & 92 & 20,0 \\
Sala de aula & 2 & 3,5 & 75 & 16,6 \\
Amigos/parentes & 2 & 3,5 & 29 & 6,4 \\
Médico & 2 & 3,5 & 8 & 1,8 \\
Outros & 5 & 8,6 & 17 & 3,7 \\
TOTAL & 58 & 100,0 & 455 & 100,0 \\
\hline
\end{tabular}

Nota: respostas múltiplas dos professores para a questão, com 58 citações obtidas. Respostas múltiplas dos alunos para a questão, com 455 citações. 
Os professores mencionaram, com maior freqüência, as revistas (não-científicas), sendo os seguintes meios citados, em proporções decrescentes: jornais e Internet, livros e artigos científicos, programa de televisão, sala de aula, amigos/parentes e médicos, sendo destacada a pequena importância da televisão (3,5\% das citações) no julgamento da superioridade de alimentos orgânicos sobre os transgênicos e a grande importância de meios de comunicação. Em se tratando do rol de citações dos alunos, observa-se a grande importância das informações provenientes dos programas de televisão e revistas , cada uma com $20 \%$ de menção.Verifica-se que as informações fornecidas em sala de aula foram mais citadas quando se compara com os percentuais de referências aos jornais, Internet e livros, o que demonstra a influência passível dos professores na “formação da opinião” dos estudantes.

Em relação os alimentos orgânicos, os professores e alunos foram ainda questionados sobre a manutenção do costume de consumir alimentos orgânicos. As respostas obtidas permitiram a elaboração da tabela 18 :

Tabela 18. Distribuição dos professores e alunos, de acordo com o costume e a freqüência de consumo de alimentos orgânicos. São Paulo,2004

\begin{tabular}{lrr}
\hline Freqüência de consumo & \multicolumn{2}{c}{ Percentual } \\
\hline Três vezes por semana ou mais & Professores & Alunos \\
Duas a três vezes por semana & 9,5 & 26,4 \\
Duas a três vezes ao mês & 9,5 & 7,6 \\
Raramente & 19,0 & 7,9 \\
Não consomem & 47,7 & 37,5 \\
Não respondeu & 11,9 & 17,3 \\
TOTAL & 2,4 & 3,3 \\
\hline
\end{tabular}


Visando a conhecer o comportamento dos alunos dos professores que integram a amostra da pesquisa, no que tange ao tema "transgênicos", foi solicitado que estes discorressem sobre as dúvidas/interesses, manifestados pelos discentes, durante as aulas sobre as propriedades/características dos alimentos transgênicos. Os dados mostram que $31 \%$ dos professores foram questionados quanto a definição de transgênicos, se estes fazem mal e solicitada a apresentação de exemplos. A preocupação em relação a possíveis repercussão sobre a saúde (danos ou benefícios) é revelada por 11,9\% dos professores. Menor parcela $(7,1 \%)$ dos entrevistados, é questionada sobre sua opinião em relação a transgênicos. Os estudos envolvendo transgênicos são abordados nas salas, durante as aulas por 7,1\% dos professores entrevistados, enquanto que comentários sobre bioética são registrados nas aulas de 2,4\% dos docentes. A diferença entre organismos geneticamente modificados e transgênicos é questionada pelos alunos de $2,4 \%$ dos entrevistados. De acordo com os docentes entrevistados, (2,4\%), são feitos vários questionamentos sobre transgênicos, como por exemplo, se é verdade que pessoas já morreram após consumir transgênicos, se eles são prejudiciais à saúde. Para similar proporção de docentes, já houve, durante as aulas, questionamento relativo à possibilidade das alterações genéticas serem passíveis de observação a "olho nu". Registro de expressiva parcela (35,7\%) dos professores , não houve questionamento, por parte dos alunos, sobre o tema "Transgênicos”. 


\section{CONCLUSÕES}

Com relação a transgênicos, a maioria dos professores soube registrar de forma geral o conceito relativo ao tema de forma apropriada, isto é, tendo por base as informações registradas na literatura da área. No entanto, cabe destacar que havia a expectativa por parte do autor de que os docentes apresentassem conceitos de forma mais detalhada ou pormenorizada, visto que foi observado que vários integrantes da amostra possuíam terceiro grau completo (graduação), e expressiva parcela, detinha títulos de pós-graduação, na área de ciências biológicas. Além disso, cabe salientar que a referida categoria (professores) integra uma classe social que tem maiores recursos para o acesso a informação, freqüentemente atuam em regiões que possuem instituições universitárias, bibliotecas especializadas entre outros recursos. Deve ser destacado também que são moradores do Estado de São Paulo, o qual está inserido na região mais desenvolvida do Brasil e portanto detentora de muitos recursos acadêmicos, entre outros.

Os alunos também forneceram, em sua maioria, respostas coerentes, relativas ao conceito de transgenia, embora também fosse verificado que as mesmas, invariavelmente se revelavam superficiais e limitadas quanto a abrangência.

De maneira similar à expectativa com relação aos professores, também era esperado que os entrevistados soubessem citar exemplos de produtos transgênicos que não fossem os alimentos. No entanto destaca-se que apenas 33,3\% dos docentes e $25 \%$ dos alunos fornecerem os referidos exemplos.

A maioria dos entrevistados não soube afirmar se alimentos/produtos transgênicos são benéficos ou maléficos ao homem, situação esperada, em virtude da escassez de informações precisas sobre as conseqüências que o consumo destes alimentos podem trazer ao homem. Ressalta-se, porém, que a coleta de dados foi realizada em um período em que o tema estava sendo discutido diariamente pela 
mídia e invariavelmente com registros de dados, resultados de pesquisas e outras informações que não possibilitam a população formar um opinião consistente sobre o assunto. O projeto de Lei de Biossegurança, que regulamenta as atividades envolvendo transgenia e as atividades com células-tronco, deveria ser aprovado no primeiro semestre de 2004 e só foi aprovado em março de 2005. Durante este período, o governo liberou o plantio e colheita de soja por meio de medidas provisórias, as quais, quando divulgadas, sempre acirravam as discussões, especialmente entre ambientalistas, órgãos de defesa do consumidor e agricultores. O projeto foi avaliado por lideranças do governo parte do ano de 2003 e todo o ano de 2004, período marcado pelos desentendimentos entre o Ministério do Meio Ambiente, Ministério da Agricultura e deputados ligados à Igreja Evangélica. Estas discussões, envolvendo a transgenia e as pesquisas com células-tronco podem ter influenciado a população brasileira, provavelmente contribuindo para confundi-la, o que pode ter dificultado a consolidação de conceitos técnicos e ainda, pouco subsidiado para que os indivíduos adotassem um posição mais decisiva sobre o tema.

É consenso entre os entrevistados a necessidade de apoio a implementação de pesquisas que visem a análise de temas relacionados a transgenia. O grupo integrante da amostra também concorda de forma majoritária com a necessidade da rotulagem dos alimentos transgênicos. Tais respostas podem ser conseqüência da formação dos professores/alunos na área de alimentos/nutrição, que tradicionalmente valoriza a importância das informações contidas nos rótulos dos alimentos.

A maioria $(64,4 \%)$ dos professores cita que é questionada em sala de aula sobre a questão dos alimentos transgênicos. Esperava-se que este percentual, embora expressivo, fosse maior, visto a extensa exposição do tema nos meios de comunicação durante o ano de 2004, poderia ter gerado maiores expectativas entre os alunos.

Pode-se dizer que o investimento em informação poderia esclarecer de maneira mais consistente os consumidores, auxiliando-os a avaliar, tendo por base,dados técnicos, questões relativamente novas, como a transgenia e biotecnologia,de forma geral. Destaca-se, nesta questão, a importância assumida pelos grandes veículos de comunicação - televisão, jornais, revistas, que alcançam distintos estratos da população e portanto, poderiam fornecer conhecimentos técnicos 
e atuais, com agilidade.Essa contribuição teria impacto também desejável mesmo sobre os grupamentos com maior escolaridade, como é o caso, por exemplo dos professores que integraram a amostra desta presente pesquisa. Também reconhecese, tendo por base os resultados e conclusões da dissertação que é imprescindível a atuação mais decisiva das universidades e centros de pesquisa no sentido de implementarem cursos de atualização nessa área, especialmente para os indivíduos que concluíram seus cursos de graduação há mais de cinco anos, período em que o volume de informações relacionadas a temas como biotecnologia, transgenia, clonagem, células-tronco aumentou substancialmente. A educação a distância poderia agilizar, facilitar e até reduzir custos das referidas iniciativas, viabilizando o acesso desses grupos. Neste caso, centros de reconhecida competência, especialmente as universidades paulistas, poderiam planejar e executar programas que viabilizassem essas experiências. Para finalizar cabe lembrar que instituições que visam o estimulo do desenvolvimento cientifico e tecnológico são importantes pilares para consolidar novas experiências de difusão e aperfeiçoamento de técnicas educativas, com destaque para a Fundação de Amparo a Pesquisa do Estado de São Paulo- FAPESP- mantém há praticamente uma década linha especifica de financiamento - "Ensino Público", que constitui recurso valioso para essas iniciativas, por exemplo, envolvendo segmentos das universidades, rede pública de ensino, com destaque no caso para a Centro Estadual de Educação Tecnológica Paula Souza, mantenedora de cursos na área de agricultura, alimentos e nutrição. 
ANEXOS 
Anexo A - Termo de Consentimento Livre e esclarecido, fornecido a cada um dos professores e alunos entrevistados, antes da etapa de coleta de dados

Termo de consentimento livre e esclarecido (TCLE)

A presente pesquisa tem como objetivo verificar a opinião de professores e alunos dos cursos técnicos em nutrição da rede pública do estado de São Paulo em relação aos transgênicos. A pesquisadora obteve autorização da coordenação de ensino médio do Centro Paula Souza para visitar cada uma das 13 escolas escolhidas para fazerem parte da pesquisa. A coordenação enviou um ofício à direção de cada escola informando sobre a visita da pesquisadora. A pesquisadora manteve contato com a direção e a coordenação de cada escola, para que fosse marcada uma data para a realização da pesquisa. Durante a visita da pesquisadora em cada escola, que pode variar de um a três dias da semana, será aplicado um questionário contendo questões objetivas e descritivas, em professores que ministram aulas para o curso técnico de nutrição e em alunos do último semestre do curso, que sejam maiores de 16 anos. O questionário, a ser respondido individualmente, exigirá aproximadamente 25 minutos da atenção do voluntário. Não será permitido que os questionários sejam respondidos fora do horário das aulas. A adoção deste questionário visa a obtenção de informações relativas à opinião dos participantes da pesquisa em relação aos alimentos transgênicos, além de informações referentes à situação socioeconômica e aos hábitos alimentares dos participantes.

É importante ressaltar que não há outro método alternativo para a obtenção das informações desejadas. Os voluntários que participarão da pesquisa não terão despesas para faze-lo. Sendo assim, não há previsão de ressarcimento. Da mesma forma, não estão previstos eventuais decorrentes da pesquisa, não sendo previsto, então, a reparação de danos. A pesquisa não trará risco à integridade física e moral de seus participantes. Os resultados e análises não serão utilizados para qualquer avaliação do desempenho escolar dos alunos e do desempenho profissional dos professores. 
As informações obtidas na pesquisa serão divulgadas em relatórios, dissertações/teses, artigos, congresso científicos, porém sem identificação do participante e da escola de origem. O pesquisador responsável garante que, durante sua visita aos colégios, os questionários respondidos pelos alunos e professores ficarão sob sua tutela, não podendo ser lido por nenhuma outra pessoa, seja diretor, aluno ou professore.

A pesquisadora responsável pela coleta de informações/dados garante o fornecimento de respostas às perguntas ou esclarecer dúvidas que possam surgir durante a implementação da pesquisa.

A participação dos alunos e dos professores é voluntária, podendo estes retirar seu consentimento e deixar de participar da pesquisa a qualquer momento sem qualquer penalidade ou prejuízo para o participante.

Cada voluntário receberá duas cópias deste termo. Um deve ser lido, preenchido e assinado, e entregue a pesquisadora, e o outro deve ficar com o voluntário.

Para contato:

1. Ana Cláudia Cayres de Mendonça (pesquisadora principal)

Rua Ernesto Papini, 343 - Nova Piracicaba

Piracicaba - SP . tel: (19) 34211296

E-mail: mendonca@esalq.usp.br

2. Prof ${ }^{\mathrm{a}}$. $\mathrm{D}^{\mathrm{ra}}$. Marina Vieira da Silva (coordenadora da pesquisa)

ESALQ/USP - Av. Pádua Dias, nº 11 Piracicaba (SP) - Depto de Agroindústria, Alimentos e Nutrição

Tel: (19) 34294225 - Fax: (19) 34322381.

E-mail:mvdsilva@esalq.usp.br 
3. Comitê de Ética em Pesquisa em Seres Humanos da Faculdade de Odontologia de Piracicaba/Unicamp

Coordenador: Jacks Jorge Junior/ Vice-coordenadora: Cinthia Pereira M. Tabchoury/ Secretária: Leny Cecília Faro Pereira Rosilho

Av. Limeira, 901 - Caixa Postal 52

Piracicaba - SP - CEP - 13414-900

Tel/Fax-CEP (0xx19) 3412-5349

Fax-FOP (0xx19) 3412-5218

E-mail: cep@fop.unicamp.br

$\mathrm{Eu}$, RG

declaro que compreendi as informações presentes neste termo de consentimento livre e esclarecido e concordo em participar nesta pesquisa.

de de 2004.

Assinatura do participante da pesquisa 
Anexo B - Questionário adotado para a obtenção de dados junto aos alunos integrantes da pesquisa

\section{UNIVERSIDADE DE SÃO PAULO}

Departamento de Agroindústria, Alimentos e Nutrição

Curso de Pós-Graduação em Ciência e Tecnologia de Alimentos

Muito obrigado por participar de nossa pesquisa de opinião sobre transgênicos. Antes de responder ao questionário, você deve ler a carta de informação e preencher e assinar o termo de consentimento livre e esclarecido, fornecidos pela pesquisadora. Por favor, responda às questões individualmente.

1. Nome (facultativo):

2. Sexo: ( ) Feminino ( ) Masculino

3. Informe a sua data de nascimento:

4. Informe a renda da sua família (soma de todos os ganhos das pessoas que dividem as despesas), aproximadamente. O valor de um salário mínimo é de R\$ 260,00 .

( ) 1 a 2 salários mínimos

( ) 11 a 15 salários mínimos

( ) 3 a 6 salários mínimos

( ) 16 a 30 salários mínimos

( ) 7 a 10 salários mínimos

( ) > 30 salários mínimos

5. Cite o número de pessoas existentes em sua família que dividem os rendimentos e compartilham o mesmo domicílio:

6. Você tem alguma outra atividade além de freqüentar a escola técnica, como estagiar ou trabalhar? Em caso afirmativo, qual é a sua atividade? 
7. Você, ao escolher algum alimento durante a compra, considera: (múltipla escolha)

( ) o preço

( ) a aparência

( ) sabor/aroma

( ) informações que assegurem a qualidade do alimento (maior durabilidade, maior quantidade de nutrientes).

( ) garantia (existência) de informação de que não há resíduos

( )outra: Qual?

8. Você alterou sua alimentação nos últimos 24 meses?

$$
\text { ( ) } \operatorname{sim} \text { ( ) não }
$$

No caso de ter recebido orientação para adotar a mudança na alimentação, marque a origem da informação (múltipla escolha):
( ) Médico
( ) informação de revista
( ) Nutricionista
( ) informação de jornal
( ) Farmacêutico
( ) informação de programa de televisão
( )Amigos/parentes
( ) outros. Qual (is):

9. Você tem algum hábito alimentar diferenciado?

( ) vegetariano

( ) naturalista

( ) macrobiótico

( ) segue algum tipo de dieta especial. Informe qual (is):

( ) motivo religioso. Informe qual (is):

( ) outros: 
10. O que você entende por produtos ou alimentos transgênicos?

11. Você tem acompanhado as notícias veiculadas pelos meios de comunicação referentes aos alimentos transgênicos? Em caso afirmativo, comente o que você tem verificado em relação a este assunto.

12. Você acredita que o Brasil possa ter uma legislação referente à biotecnologia? Em caso afirmativo, o senhor (a) poderia nos explicar em que possa consistir esta legislação?

13. Você acredita que os alimentos transgênicos:

( ) säo benéficos à saúde.

( ) causam danos à saúde

( ) indiferente

( ) não tem opinião

( ) outros:

14. Você poderia citar algum (s) produto (s) transgênico (s) que não seja (m) alimento (s)? 
15. Você acredita na necessidade de se disponibilizar os alimentos transgênicos para a população de nosso país?

( ) $\operatorname{sim}$

( ) não

( ) não tem opinião

16. Você acredita que o emprego de sementes transgênicas na agricultura possa alterar os preços dos grãos, e, conseqüentemente os preços dos alimentos nos pontos de venda?

17. Você acredita que a disponibilidade de alimentos transgênicos nos países poderá alterar seus preços e, conseqüentemente, controlar a fome no Mundo?

18. Você concorda com o aumento de recursos destinados a pesquisas científicas, no Brasil, envolvendo organismos transgênicos?

19. Você é a favor da rotulagem de alimentos transgênicos?

( ) $\operatorname{sim}$

( ) não

( ) não tem opinião 
20. Na sua opinião, a população brasileira tem consumido alimentos transgênicos sem prévio conhecimento?

21. Suponha que um quilo de algum alimento custasse 1 real. Você estaria disposto a pagar quanto pelo alimento, se ele tivesse garantia de ser um alimento não transgênico?
( ) não pagaria a mais para ter esta garantia
( ) 1,50 reais
( ) 1,10 reais
( ) 1,75 reais
( ) 1,30 reais
( ) mais de 2,00 reais.

22. Na sua opinião, a utilização de sementes transgênicas afeta o meio ambiente?

( ) sim. Por quê?

( ) não. Por

quê?

( ) não tem opinião.

23. Você concorda no emprego de alimentos transgênicos (soja, milho) na ração para animais?

( ) sim. Por quê

( ) não. Por quê?

( ) não tem opinião. 
24. Você acredita que os alimentos orgânicos são superiores, qualitativamente, em comparação com os transgênicos?

( ) sim. Por quê?

( ) não. Por quê?

( ) não tem opiniäo

25. Em caso afirmativo, de onde obteve as informações sobre a superioridade dos orgânicos? (múltipla escolha)

( ) livros

( ) televisão

( ) sala de aula

( ) revistas

( ) Internet

( ) amigo/parente

( ) jornal

( ) médico

( ) outros. Qual (is):

26. Você costuma consumir alimentos orgânicos?
( ) não
( ) sim, duas ou três vezes ao mês
( ) sim, raramente
( ) sim, três vezes ou mais por semana
( ) sim, uma vez por semana

Data do preenchimento:................... 
Anexo C: Questionário adotado para a obtenção de dados junto aos professores integrantes da pesquisa

\author{
UNIVERSIDADE DE SÃO PAULO \\ Departamento de Agroindústria, Alimentos e Nutrição \\ Curso de Pós-Graduação em Ciência e Tecnologia de Alimentos
}

Muito obrigado por participar de nossa pesquisa de opinião sobre transgênicos. Antes de responder ao questionário, você deve ler a carta de informação e preencher e assinar o termo de consentimento livre e esclarecido, fornecidos pela pesquisadora. Por favor, responda às questões individualmente.

1. Nome (facultativo):

2. Sexo: ( ) Feminino ( ) Masculino

3. Informe o dia, mês e ano de seu nascimento:...................

4. Informe a sua escolaridade:

Informe o seu curso de graduaçäo:

pós-graduação: ( stricto - sensu (mestrado ou doutorado)

( ) lato - sensu (especialização ou aperfeiçoamento)

( ) não tem pós-graduação

5. Por favor, informe o tempo que o senhor (a) exerce a atividade de professor (a) em escola técnica:

6. Informe o número de aulas e a carga horária total que o senhor (a) ministra por semana:

7. Você tem alguma outra atividade, além de ministrar aulas na escola técnica? Em caso afirmativo, informe que tipo de atividade: 
8. Informe a renda da sua família (soma de todos os ganhos das pessoas que dividem as despesas), aproximadamente. O valor de um salário mínimo é de R\$ 240,00 .

( ) 1 a 2 salários mínimos

( ) 11 a 15 salários mínimos

( ) 3 a 6 salários mínimos

( ) 16 a 30 salários mínimos

( ) 7 a 10 salários mínimos

( ) > 30 salários mínimos

9. Cite o número de pessoas existentes em sua família que dividem os rendimentos e compartilham o mesmo domicilio:

10. Informe o seu ganho mensal. O valor de um salário mínimo é de R 240,00.

( ) 1 a 2 salários mínimos

( ) 11 a 15 salários mínimos

( ) 3 a 6 salários mínimos

( ) 16 a 30 salários mínimos

( ) 7 a 10 salários mínimos

( ) > 30 salários mínimos

11. O (a) senhor (a), ao escolher algum alimento durante a compra, considera (múltipla escolha):

( ) o preço

( ) a aparência

( ) sabor/aroma

( ) informações que assegurem a qualidade do alimento (maior durabilidade, maior quantidade de nutrientes).

( ) garantia (existência) de informação de que não há resíduos

( )outra: Qual?

12. O (a) senhor (a) alterou sua alimentação nos últimos 24 meses?
( ) $\operatorname{sim}$
( ) não 
No caso de ter recebido orientação para adotar a mudança na alimentação, marque a origem da informação (múltipla escolha):
( ) Médico
( ) informação de revista
( ) Nutricionista
( ) informação de jornal
( ) Farmacêutico
( ) informação de programa de televisão
( )Amigos/parentes
( ) outros. Qual (is):

13. O senhor (a) tem algum hábito alimentar diferenciado?

( ) vegetariano

( ) naturalista

( ) macrobiótico

( ) segue algum tipo de dieta especial. Informe qual (is):

( ) motivo religioso. Informe qual (is):

( ) outros:

14. O que o (a) senhor (a) entende por produtos ou alimentos transgênicos?

15. O senhor (a) tem acompanhado as notícias veiculadas pelos meios de comunicação referentes aos alimentos transgênicos? Em caso afirmativo, comente o que o senhor (a) tem verificado em relação a este assunto.

16. O senhor (a) acredita que o Brasil possa ter uma legislação referente à biotecnologia? Em caso afirmativo, o senhor (a) poderia nos explicar em que poderia consistir esta legislação? 
17. O senhor (a) acredita que os alimentos transgênicos:

( ) säo benéficos à saúde.

( ) causam danos a saúde

( ) indiferente

( ) não tem opinião

( ) outros:

18. O senhor (a) poderia citar algum (s) produto (s) transgênico (s) que não seja (m) alimento (s)?

19. O senhor (a) acredita na necessidade de se disponibilizar os alimentos transgênicos para a população de nosso país?

( ) $\operatorname{sim}$

( ) não

( ) não tem opinião

20. O senhor (a) acredita que o emprego de sementes transgênicas na agricultura possa alterar os preços dos grãos e, conseqüentemente os preços dos alimentos nos pontos de venda? 
21. O senhor (a) acredita que a disponibilidade de alimentos transgênicos nos países possa alterar os seus preços e, conseqüentemente, controlar a fome no Mundo?

22. O senhor (a) concorda com a implementação de estímulos /recursos, pelo governo para intensificar as pesquisas científicas, no Brasil, envolvendo organismos transgênicos?

23. O senhor (a) é a favor da rotulagem de alimentos transgênicos?

( ) $\operatorname{sim}$

( ) não

( ) não tem opinião

24. A existência de legislação especifica sobre rotulagem de transgênicos no Brasil na sua opinião vai:

( ) ser cumprida ( ) não vai ser cumprida （ ) não sabe

25. Na sua opinião, qual deveria ser a penalidade para aqueles que descumprirem a legislação:

Registre também qual (is) o (s) órgão (aos) que deveria (m) assumir a fiscalização sobre a rotulagem dos alimentos

transgênicos:

26. O senhor (a) acredita que a liberação de transgênicos possa contribuir para a melhora da economia brasileira? ( ) sim （ ） não ( ) não sabe

Em caso afirmativo, por quê? 
27. Na sua opinião, a população brasileira tem consumido alimentos transgênicos sem prévio conhecimento?

28. Suponha que um quilo de algum alimento custasse 1 real. O senhor (a) estaria disposto a pagar quanto pelo alimento, se ele tivesse garantia de ser um alimento não transgênico?
( ) não pagaria a mais para ter esta garantia
( ) 1,50 reais
( ) 1,10 reais
( ) 1,75 reais
( ) 1,30 reais
( ) mais de 2,00 reais.

29. Na sua opiniäo, a utilização de sementes transgênicas afeta o meio ambiente?

( ) sim. Por quê?

( ) não. Por quê?

( ) não tem opinião.

30. O senhor (a) concorda no emprego de alimentos transgênicos (soja, milho) na ração para animais?

( ) sim. Por quê?

( ) não. Por quê?

( ) não tem opinião. 
31. O senhor (a) acredita que os alimentos orgânicos säo superiores, qualitativamente, em comparação com os transgênicos?

( ) sim. Por quê?

( ) não. Por quê?

( ) não tem opiniäo

32. Em caso afirmativo, de onde obteve as informações sobre a superioridade dos orgânicos? (múltipla escolha)

( ) livros

( ) televisão

( ) sala de aula

( ) revistas

( ) Internet

( ) amigo/parente

( ) jornal

( ) médico

( ) outros. Qual (is):

33. O senhor (a) costuma consumir alimentos orgânicos?
( ) não
( ) sim, duas ou três vezes ao mês
( ) sim, raramente
( ) sim, três vezes ou mais por semana
( ) sim, uma vez por semana

31. Durante as suas aulas, os alunos têm questionado sobre as propriedades/características dos alimentos transgênicos? Em caso afirmativo, registre quais são as dúvidas predominantes.

Data do preenchimento:.................. 


\section{REFERÊNCIAS BIBLIOGRÁFICAS}

AZEREDO, R.M. A Biotecnologia e segurança alimentar. In: COSTA, N.M.B.; BORÉM, A. Biotecnologia e nutrição: saiba como o DNA pode enriquecer os alimentos. São Paulo: Nobel, 2003. cap.1, p. 13-31.

BORÉM, A.; SANTOS, F.R. Biotecnologia e segurança alimentar. In: BORÉM, A. , COSTA, N.M.B. Biotecnologia e nutrição: saiba como o DNA pode enriquecer os alimentos. São Paulo: Nobel, 2003. cap.1, p. 13-31.

BORÉM, A.; COSTA, N.M.B.; AZEREDO, R.M.C. Alimentos geneticamente modificados - um assunto polêmico. Nutrição em Pauta, N. 61 p. 8-16, jul./ago 2003.

BRASIL. Decreto n⿳0 4.680, 24 de abril de 2003. http://www.mct.gov.br/legis/decretos/4680_2003.htm (08 jun. 2003 a).

BRASIL. Instrução Normativa número 18, 15 de dezembro de 1998. http://www.mct.gov.br/legis/outros_atos/in18_98.htm (07 jun.2003b).

BRASIL. Lei $\mathbf{n}^{\mathbf{0}} \mathbf{1 0 . 6 8 8}, 13$ de junho de 2003. http://www.mct.gov.br/legis/leis/10688_2003.htm (01 set. 2004b).

BRASIL. Lei $\mathbf{n}^{\mathbf{0}} \mathbf{8 . 0 7 8}, 11$ de setembro de 1990. Código de defesa do consumidor http://www.mj.gov.br/dpdc (20 set. 2004c).

BRASIL. Lei $\mathbf{n}^{\mathbf{0}}$ 11.092, de 12 de janeiro de 2005. http://www.mct.gov.br/legis/leis/11092_2005.htm (31 jan. 2005).

BRASIL. Medida Provisória no 2.191-9, 23 de agosto de 2001. http://www.mct.gov.br/legis/mp/mp2191-9.htm (08 jun. 2003c).

BRASIL. Medida Provisória no 113, 26 de março de 2003. http://www.mct.gov.br/legis/mp/mp113_2001.htm (08 jun. 2003b). 
BRASIL. Portaria MJ 2658, 17 de dezembro de 2003. http://www.mct.gov.br/lportarias/2658_2003.htm (11 abr.2004a).

BRASIL. Lei no 10814, 15 de dezembro de 2003. http://www.mct.gov.br/legis/leis 10 814_2003htm (10 jun. 2004d).

BRASIL. Medida Provisória no 131, 25 de setembro de 2003. http://www.mct.gov.br/legis/mp/mp131_2003.htm (29 set. 2004e).

BRASIL. Medida Provisória no 223, 14 de outubro de 2004. http://www.mct.gov.br/legis/mp/mp223_2004htm ( 16 out.2004f).

CAROBA, D.C.R. A escola e o consumo alimentar de adolescentes matriculados na rede pública de ensino. Piracicaba, 2000, 162 p. Dissertação (Mestrado) - Escola Superior de Agricultura Luiz de Queiroz, Universidade de São Paulo.

COCKBURN, A. Assuring the safety the genetically modified (GM) foods: the importance of an holistic, integrative approach. Journal of Biotechnology, v. 98, n 11 p. $79-106$, Sept. 2002.

COMISSÃO TÉCNICA NACIONAL DE BIOSSEGURANÇA http://www.ctnbio.gov.br (24 abr. 2005).

CONSELHO DE INFORMAÇÕES SOBRE BIOTECNOLOGIA. http://www.cib.org.br/ (30 jun.2005).

COSTA, N.M.B.; BORÉM, A. Biotecnologia e nutrição: saiba como o DNA pode enriquecer os alimentos. São Paulo: Nobel, 2003. 214p.

DONALDSON, L. ; MAY, R. Healthy implications of genetically modified foods. London: Department of Healthy. http://www.dh.gov.uk/assetRoot/04/06/50/90/04065090.pdf. (20 jul. 2005).

FUNDAÇÃO SISTEMA ESTADUAL DE ANÁLISE DE DADOS. http://www.seade.gov.br/ (22 dez. 2004).

INSTITUTO BRASILEIRO DE GEOGRAFIA E ESTATÍSTICA: Produção agrícola municipal cereais, leguminosas e oleaginosas. Rio de Janeiro, 2005. 54 p. http://www.ibge.gov.br/home/estatistica/economia/pamclo/2004/pamclo2004.pdf ( 25 jul. 2005) 
INTERNATIONAL SERVICE FOR THE ACQUISITION OF AGRI-BIOTECH APPLICATION

http://www.isaaa.org/kc/CBTNews/press_release/briefs30/es_b30_portuguese.pdf (26 jun. 2005).

LAJOLO, F.M.; NUTTI, M.R. Transgênicos: bases científicas da sua segurança. São Paulo: SBAN, 2003.112p.

LEITE, M. Os Alimentos Transgênicos. São Paulo: Publifolha, 2000. 89 p.

MORAIS, R. J. Segurança e rotulagem de alimentos geneticamente modificadosSERAGEM: uma abordagem do direito econômico. Rio de Janeiro: Forense, 2005. 206p.

ODA, L.M.; SOARES, B.E.C. Biotecnologia no Brasil: aceitabilidade pública e desenvolvimento econômico. Brasília: Ministério da Ciência e Tecnologia, 2001. 266p. (Parcerias Estratégicas, 10)

ORGANIZAÇÃO MUNDIAL DA SAÚDE. Moderna biotecnologia de alimentos, saúde humana e desenvolvimento.

htpp://www.who.int/foodsafety/publications/biotech/biotech_sp.pdf (30 jun. 2005).

ORGANIZAÇÃO PARA COOPERAÇÃO E DESENVOLVIMENTO ECONÔMICO. http://www.olis.oecd.org/olis/1997doc.nsf/43bb6130e5e86e5fc12569fa005d004c/65 6a6ffd5ec500d0c1256b6e00372ca1/\$FILE/JT00121603.PDF (24 jun.2005a).

ORGANIZAÇÃO PARA COOPERAÇÃO E DESENVOLVIMENTO ECONÔMICO http://www.oecd.org/dataoecd/57/3/1946129.pdf (25 jun.2005b).

PELICIONE, M .C. F. TORRES, A.L A escola promotora de saúde. São Paulo: USP, Faculdade de Saúde Pública, 1999. 13 p. (Série Monográfica, 12).

PIPITONE, M.A.P. A relação saúde e educação na escola de primeiro grau. Alimentação e Nutrição. n. 65, p.48-52, 1995.

SAS INSTITUTE. The SAS System (software): versão 8. Cary, 1998.

SOUZA, T.L. Comentários sobre a política das comunidades européias para transgênicos à luz do Acordo sobre Barreiras Técnicas ao Comércio. ponto focal de barreiras técnicas às exportações http://www.inmetro.gov.br/barreirastecnicas (04 set. 2004). 